\title{
Equids from Emine-Bair-Khosar Cave (Crimea, Ukraine): co-occurrence of the stenonid Equus hydruntinus and the caballoid $E$. ferus latipes based on skull and postcranial remains
}

\author{
Eline N. van Asperen, Krzysztof Stefaniak, lurii Proskurnyak, and Bogdan Ridush
}

\begin{abstract}
The Late Pleistocene faunal assemblages excavated from the cave Emine-BairKhosar in the Chatyrdag Massif in the Crimean Mountains, Ukraine, contain about 250 equid remains. Detailed morphological analyses reveal the occurrence of the small, stenonid species Equus hydruntinus alongside a large, caballoid species identified as Equus ferus latipes. The presence in the assemblage of two extremely well-preserved skulls of Equus hydruntinus is highly significant and contributes much to our knowledge of this enigmatic Pleistocene species. These skulls, as well as a skull of Equus ferus latipes, are here described and compared to skulls of closely related species. The $E$. hydruntinus skulls stand out amongst related equids by their short muzzles, an adaptation to cold climatic conditions. Complete postcranial bones are also frequent in the sample for both species, with relatively robust longbones for Equus hydruntinus similar to those of other Late Pleistocene E. hydruntinus samples. The presence of a long-limbed form of Equus ferus latipes indicates that the environmental conditions under which the assemblage accumulated were relatively cool but favourable for equids. The relative abundances of the two species in the assemblage are in accordance with land use patterns documented for extant relatives.
\end{abstract}

Eline N. van Asperen. Research Centre in Evolutionary Anthropology and Palaeoecology, School of Natural Sciences and Psychology, Liverpool John Moores University, Liverpool and Centre for Anatomical and Human Sciences, Hull York Medical School, University of York, United Kingdom envanasperen@palaeo.eu

Krzysztof Stefaniak. Department of Palaeozoology, Zoological Institute, University of Wrocław, Wrocław, Poland stefanik@biol.uni.wroc.pl

lurii Proskurnyak. Department of Paleozoology and Paleontological Museum, National Museum of Natural History of the National Academy of Science of Ukraine, Kiev, Ukraine yra.shustrik@gmail.com Bogdan Ridush. Department of Physical Geography and Natural Management, Chernivtsi "Fedkovych" National University, Chernivtsi, Ukraine ridush@yahoo.com

KEYWORDS: Equidae; skeletal morphology; Late Pleistocene; Crimea 


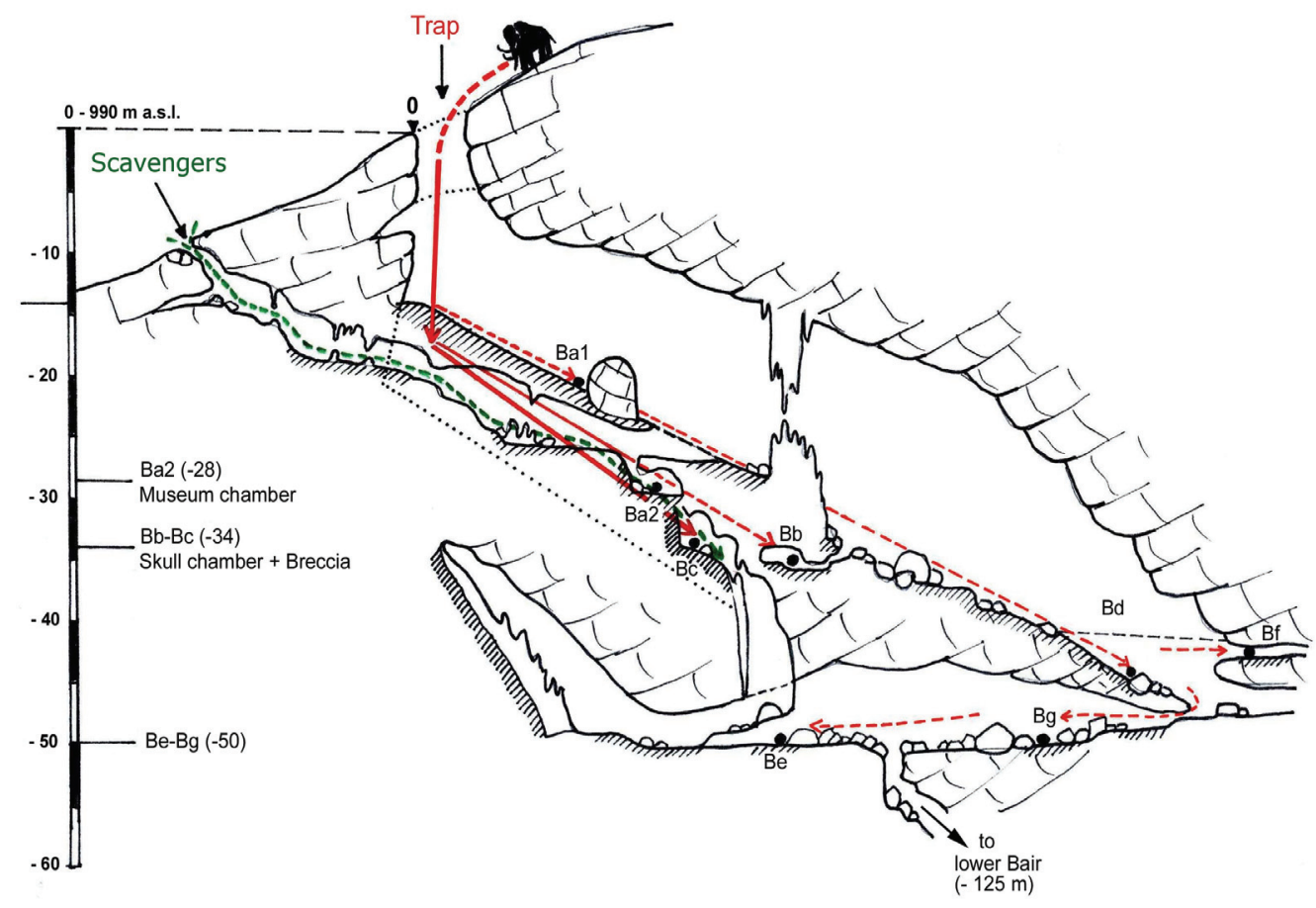

FIGURE 1. Cross-section through the Emine-Bair-Khosar Cave (Vremir and Ridush, 2005).

\section{INTRODUCTION}

The cave site Emine-Bair-Khosar (EBK, $44^{\circ} 48^{\prime} 04.60^{\prime \prime} \mathrm{N} / 34^{\circ} 17^{\prime} 22.00^{\prime \prime} \mathrm{E}$ ) is located on the northern edge of the Lower Plateau of the Chatyrdag Massif in the Crimean Mountains, Ukraine. A vertical shaft with a diameter of several meters forms the main entrance to the cave, which with a total length of $1460 \mathrm{~m}$ and a depth of $125 \mathrm{~m}$ is one of the largest caves in this karstic area (Vremir and Ridush, 2005). The vertical shaft through which the animals entered or fell into the cave was probably open during most of the Pleistocene. The faunal assemblages recovered from the cave therefore potentially accumulated over a significant period of time during the Middle to Late Valdai (Vremir and Ridush, 2005). In the 1960s, 180 bones belonging to 24 individuals of Ursus spelaeus were collected in the lateral gallery (Northern Gallery), as well as remains of Canis lupus, Vulpes corsac, Felis spelaea, Lynx lynx, Equus caballus, Cervus elaphus, and Lepus sp. Another entrance probably existed in this part of the cave in the Late Pleistocene. Although the exact stratigraphical origin of these finds is unknown, the assemblage is believed to represent a carnivore den (Dublyansky and Lomaev, 1980).

Further excavations taking place between 1999 and 2005 revealed faunal assemblages at nine locations in the cave in several stratigraphic units (Figure 1), with more than 5000 specimens of at least 35 species of mammals, birds, and reptiles being recovered from the richest accumulations at locations $\mathrm{Bb}$ and Bc (Stankovic et al., 2011). At location $\mathrm{Bb}$, a bone breccia of at least $2 \mathrm{~m}$ thick was discovered in the accumulation of limestone blocks that forms the base of the talus cone under the entrance shaft, at a depth of 7-8 $\mathrm{m}$ below the talus surface. The breccia shows no clear internal stratigraphy, and the bones recovered from this deposit are thought to represent a single depositional phase. Due to its faunal composition, which includes several thermophilic species such as Sus scrofa, the deposit is dated to an early part of the Last Glacial, although an earlier date in a temperate stage cannot be excluded.

The Skull Chamber (location Bc) preserved several partial and whole skeletons, which accumulated in partial association during a number of distinct episodes. The bones were recovered from a depth of 37 to $41 \mathrm{~m}$ below the shaft entrance. Absolute dating of material from this location is currently in progress (S. Constantin, personal commun., 2011).

In 2005-2010 studies focused on the Ba location, where faunal remains are embedded in limestone debris, which was produced by weathering 
TABLE 1. Radiocarbon dates (uncalibrated) for bones from various layers at the Ba site in Emine Bair Khosar Cave (Stankovic et al., 2011; A. Nadachowski, K. Stefaniak, and B. Ridush, personal commun. 2011).

\begin{tabular}{|l|l|l|c|c|}
\hline \multicolumn{1}{|c|}{ Layer } & \multicolumn{1}{|c|}{ Laboratory no. } & \multicolumn{1}{c|}{ Material } & $\begin{array}{c}\text { Depth } \\
(\mathbf{m})\end{array}$ & Radiocarbon date \\
\hline E & Poz-28732 & Bone (Cervus elaphus) & 1.65 & $12,050 \pm 60 \mathrm{BP}$ \\
G & Poz-35028 (sample J24) & Bone (Cervus elaphus) & 2.40 & $33,100 \pm 400 \mathrm{BP}$ \\
H & Poz-35027 (sample JM1) & Tooth (Cervus elaphus) & 3.20 & $42,000 \pm 1,200 \mathrm{BP}$ \\
Deepest part of profile & Poz-28893 & Bone (Saiga tatarica) & 4.60 & $48,500 \pm 2,000 \mathrm{BP}$ \\
Deepest part of profile & Poz-35026 (sample J46) & Bone (Cervus elaphus) & 4.60 & $>47,000 \mathrm{BP}$ \\
Deepest part of profile & Poz-28731 & Bone (Cervus elaphus) & 4.70 & $>46,000 \mathrm{BP}$ \\
\hline
\end{tabular}

within the entrance part of the cave, and in loess and soil sediments transported into the cave through the vertical shaft. The deposits, excavated to a depth of $6 \mathrm{~m}$, occur at a depth of 28 to $34 \mathrm{~m}$ below the shaft entrance. The lowermost layers are thought to overlap with the upper part of the Bc sediments. A fauna of over 30 species of mammals, birds, and reptiles, as well as a mollusc assemblage, was recovered from the Ba sequence (Vremir and Ridush, 2005; Stankovic et al., 2011). The upper $2.6 \mathrm{~m}$ of sediment is subdivided into seven units (layers A-G; Bondar and Ridush, 2009; Stankovic et al., 2011). Magnetostratigraphic dating is currently being applied to the subhorizontal layering at the Ba location, which preserves secular variation in the earth's magnetic field (Bondar and Ridush, 2009; Stankovic et al., 2011). Sediments at the $\mathrm{Ba}$ location are correlated with the Vitachiv warm stage, which is dated to OIS 3 , between 55 and 27 kyr BP (Rousseau et al., 2001; Gerasimenko, 2007). The climate was cool to cold and dry, with a variety of steppic environments in the vicinity of the cave (Vremir and Ridush, 2005; Gerasimenko, 2007). Radiocarbon dates are summarised in Table 1.

Here we present the remarkable equid assemblage from the 1999-2009 field seasons, which includes three well-preserved skulls and several fragmentary crania, as well as dental and postcranial elements. Visual inspection of the EBK equid remains clearly indicates that the sample includes material of different sizes and morphology. The distribution of several equid species overlapped spatially and/or temporally in this region during the time period represented in the assemblage, including both caballoid and hemione or ass-like species (Kuzmina, 1997; Stewart, 2007). The objectives for the analysis of the EBK remains therefore were to establish whether the sample contains multiple species, to investigate which species are present, and to assess the possible spatiotemporal co-occurrence of equids from different lineages against the background of the behavioural characteristics of their extant relatives. Furthermore, the occurrence of several virtually complete equid skulls provides a rare opportunity to study Pleistocene equid cranial morphology, while the abundance of postcranial remains extends our knowledge of equid ecomorphology and biogeography.

\section{MATERIALS AND METHODS}

\section{Material}

The material presented here comprises all the horse material recovered from the cave to date $(n=249)$. All material is stored in the local museum of the Center of Speleotourism "Onix-Tur," located on the Chatyrdag plateau near the Emine-BairKhosar Cave. The great majority of the specimens comes from locations $\mathrm{Ba}(\mathrm{n}=52), \mathrm{Bb}(\mathrm{n}=60)$ and $\mathrm{Bc}$ $(n=137)$. At location $\mathrm{Ba}$, the specimens are concentrated in unit $\mathrm{H}$, with a few specimens from the adjacent unit I. Nearly all equid specimens from this location were recovered from depths between 4.7 and $5 \mathrm{~m}$, thus forming a relatively distinct horizon. Another concentration of equid remains occurs at a depth of $3.9 \mathrm{~m}$. Both these horizons fall within Unit $\mathrm{H}$, which was dated to $42,000 \pm 1,200$ BP (uncalibrated radiocarbon date, Table 1). Most skeletal elements are represented in the assemblage, and many fossils show excellent preservation. Fragmentation is relatively limited, and although a number of elements bear traces of carnivore activity and rodent gnawing, a considerable part of the sample was not disturbed by biological or geological processes.

Material of extant and fossil caballoid, stenonid, and asinid equids was used for comparative purposes. For extant caballoids, remains from wild and zoo-reared Equus przewalskii were included in the study (Eisenmann, 1979, 1980, 1991; Dive and Eisenmann, 1991; Kuzmina, 1997; Eisenmann, online data: http://www.vera-eisenmann.com). Two species of fossil caballoid equids were included to investigate the specific affinities of 
the large EBK equids. These species were chosen according to their stratigraphic and geographic range and the availability of a large comparative sample. The sample for Equus gallicus, a Late Pleistocene caballoid horse from Western Europe, is from the French site Jaurens (Cardoso and Eisenmann, 1989; Eisenmann, online data (http:// www.vera-eisenmann.com). For Equus latipes, which has a more easterly distribution, a sample from the Upper Palaeolithic site Kostenki, Russia, is examined (Eisenmann, 1991; Kuzmina, 1997). These two species are alternatively regarded as subspecies or ecotypes of a single widespread species and referred to as Equus caballus gallicus and Equus caballus latipes, respectively (Kuzmina, 1997; Bignon, 2003; Eisenmann, 2004). This study follows Kuzmina (1997) in this respect, as previous analyses have shown that the variation observed in fossil caballoid equids can best be interpreted as ecomorphological variation (van Asperen, 2010, in press). However, instead of the species name Equus caballus, use of which should be confined to domesticated animals in accordance with guidelines of the International Commission on Zoological Nomenclature (ICZN 2003), we use the species name Equus ferus, as proposed by van Asperen (2010, in press), and following common usage of this species name for Pleistocene horses from the British Isles (e.g., Schreve, 1997) and Northwest and Central Europe (Cramer, 2002).

In Asia, Equus hemionus is the sole remaining extant stenonid species. Modern data for the species, which function as an important reference sample in many studies of fossil equids, were included in this study (Eisenmann, 1979, 1980, 1981, 1991; Dive and Eisenmann, 1991; Eisenmann, online data: http://www.vera-eisenmann.com). Data from several fossil samples of Equus hydruntinus, also known as the European wild ass, comprise material from the Middle Pleistocene site Lunel-Viel (France; Bonifay, 1991; Burke et al., 2003), the Late Pleistocene Crimean sites Kabazi II (Burke et al., 2003), Chokurcha and Starosele (Kuzmina, 1997), and the Italian Late Pleistocene sites Romanelli and San Sidero (Eisenmann and Bekouche, 1986). For comparison, modern remains of the African wild ass Equus africanus (Eisenmann, 1979, 1980, 1981; Dive and Eisenmann, 1991 [Equus asinus]) were also investigated.

\section{Methods}

All skeletal elements were measured with vernier callipers, and measurements were recorded to
$0.1 \mathrm{~mm}$. The skull and mandible were measured following Eisenmann (1980), with the addition of palatal length (measurement 2 - measurement 5). It should be kept in mind that cranial lengths tend to be less influenced by postdepositional distortion than widths (Eisenmann and Baylac, 2000). Measurements of the postcranial bones were taken according to Eisenmann (1979, metapodials), Eisenmann et al. (1988, humeri, radii, femora, tibiae and third phalanges), Dive and Eisenmann (1991, first phalanges), and Von den Driesch (1976, all other elements). For the dental material, mesiodistal length, and buccolingual width, and on the upper premolars and molars the length of the protocone, were measured on the occlusal surface without cement, and tooth height was measured on the buccal aspect from the division of the roots to the occlusal surface (Eisenmann, 1980, 1981). Since it is very difficult to distinguish between the third and fourth premolar and between the first and second molar when isolated teeth are examined, these were analysed together, as third / fourth premolar and first / second molar, respectively. In the following sections, the maxillary dentition is indicated as P2-4 and M1-3 and the mandibular dentition as p2-4 and m1-3. Measurements on the cranial and postcranial bones are abbreviated with 'V,' e.g., V1 = measurement 1. The full dataset for the equid remains from Emine-Bair-Khosar can be found in Appendix 1, whilst summary statistics of the Emine-Bair-Khosar equid remains and comparative samples are provided in Appendices 2-8.

In addition to these quantitative measures, several qualitative traits were scored on the dental elements (Figure 2; Eisenmann, 1980, 1981). The traits chosen vary between the different equid lineages and species. On the upper premolars and molars, the development of the pli caballin (absent, weakly developed, or strongly developed), the number of folds on the fossettes and the shape of the protocone were noted. On the lower cheek teeth, the shape of the double knot and vestibular groove were described.

Histograms and scatterplots were used to investigate the possible presence of more than one size group in the sample. The various equid lineages differ consistently in the morphology of their skulls, metapodials and first phalanges (Eisenmann, 1979; 1980; Dive and Eisenmann, 1991). These bones are therefore investigated in more detail using log ratio diagrams, in which the logarithms of the measurements are plotted against a standard (Simpson, 1941; Simpson et al., 1960). Such diagrams show both absolute differences in 


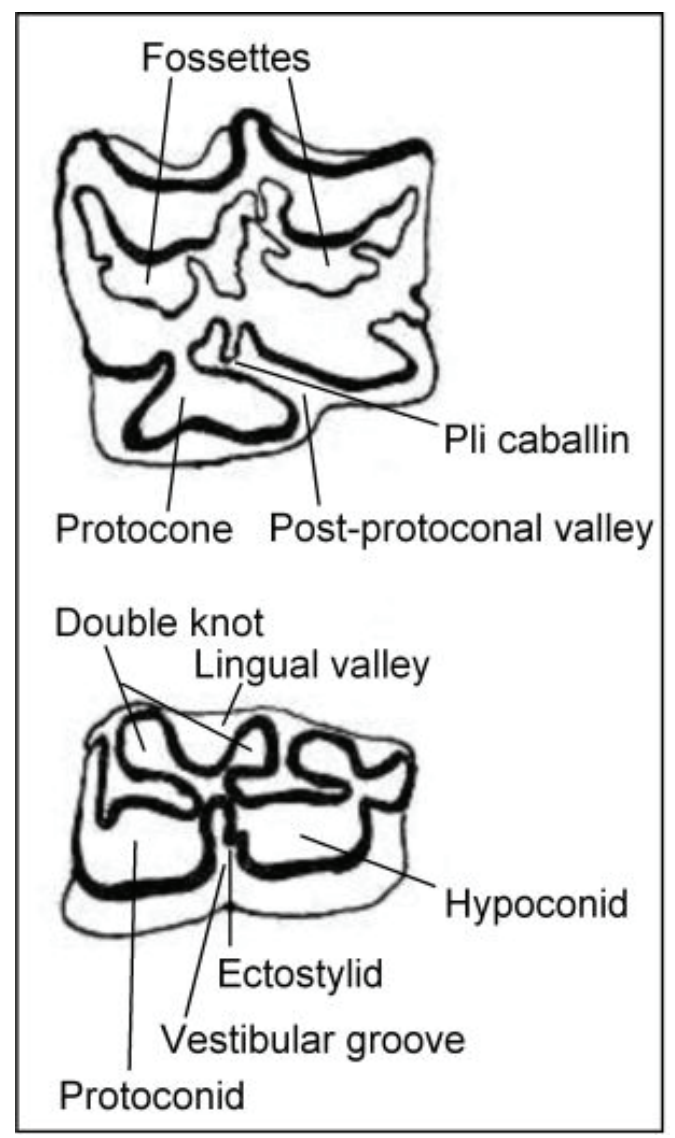

FIGURE 2. Terminology used to refer to particular dental traits.

the same dimensions on different specimens (vertical distance on the same measurement) and relative size differences (relative size changes between different measurements), the latter of which gives information about shape differences between the various samples. One specimen or group of specimens is taken as the standard of comparison, representing the base line or reference line of the diagram. In this study, the standard chosen is a sample of Equus hemionus, the species most commonly used as a standard for log ratio diagrams of Pleistocene horse remains (e.g., Eisenmann, 1979; Dive and Eisenmann, 1991). The order in which the measurements appear in the diagrams is chosen according to the differential survival of different parts of the bone, such that measurements that often cannot be taken on incomplete specimens are at both ends of the axis, while measurements that show characteristic proportions in particular equid groups are placed next to each other (Eisenmann, 1979).

\section{Detecting Species Differences in Ffossil Equids}

It is notoriously difficult to distinguish individuals of different equid species from each other based on morphological criteria, especially when data sets are small (Eisenmann, 1979, 1986; Eisenmann and Bekouche, 1986; Dive and Eisenmann, 1991; Orlando et al., 2009; van Asperen, in press). Furthermore, intraspecific variation can be high in comparison with interspecific variation. The recent recognition of sussemiones in the Late Pleistocene of Siberia (Orlando et al., 2009; Eisenmann, 2010), as well as possible occurrences of both caballoid equids and stenonid species, necessitated detailed morphological investigation of the EBK sample.

During the Pleistocene caballoid horses usually were of larger body size than stenonid equids. Furthermore, there are clear differences in dental, cranial, and postcranial morphology between caballoids and stenonids, making recognition of the presence of both groups often relatively straightforward. Several skull measurements reliably distinguish between the equid lineages. According to Franck's Index, postvomeral cranial length (V4) is larger than vomero-palatal length (V3) in caballoids (Forstén, 1999; Eisenmann, 2006). Using the Palatal Index, in caballoid equids palatal length (V2-V5) is larger than vomero-palatal length $+20 \mathrm{~mm}$ (Eisenmann, 2006). Dental and postcranial morphology reflects the fundamentally different adaptations of caballoid versus asinid and stenonid horses. The former are adapted to more humid, more closed and often cooler environments, and accordingly they have robust limb bones, broad metapodials and phalanges (Eisenmann, 1979; Kuzmina, 1997). By contrast, equids adapted to drier, warmer, and more open landscapes have slender limb bones and narrow metapodials and phalanges. The latter group, which includes asinid and stenonid equids, is further characterised by more cursorial limb proportions, with relatively long distal limb segments (Eisenmann, 1984, 1991).

Distinguishing between Equus hydruntinus, $E$. hemionus and sussemiones is rather more difficult. Sussemiones form a separate monophyletic group with no extant relatives that have recently been recognised in mtDNA analyses of specimens from Khakassia in southwest Siberia (Orlando et al., 2009). Although the specimens were initially identified as $E$. hydruntinus in morphological analyses, new appraisals of their dental traits confirm they are closely related to primitive Middle Pleistocene sussemione species such as E. suessenbornensis (Eisenmann, 2010), while their metapodial mor- 
phology is not distinct from that of E. hydruntinus (Orlando et al., 2009; Eisenmann, 2010). Similar specimens have been recovered from sites in Altai. These finds indicate that sussemione species, which were thought to have gone extinct much earlier, around 0.5 Ma (Eisenmann, 2006), survived into the Late Pleistocene.

Equus hydruntinus is characterised by a mixture of primitive characters found in fossil species such as $E$. stenonis and derived features of extant hemiones and zebras (Orlando et al., 2006). Cranial characteristics that separate the species from caballoid horses, asses, and zebras include a wide but short muzzle as in hemiones (V5, V17; Eisenmann, 1980; Burke et al., 2003; Orlando et al., 2006). The mandibular symphysis is long and narrow as in E. stenonis (Eisenmann, 1980; Eisenmann and Mashkour, 1999; Forstén, 1999). The species is often microdont, with small teeth relative to the size of the postcranial elements (Stehlin and Graziosi, 1935; Eisenmann and Baryshnikov, 1994). Although the teeth are smaller than in $E$. hemionus, the upper cheek teeth overlap in size with those of asses and hemiones (Burke et al., 2003; Orlando et al., 2006). The upper teeth have traits in common with asses and zebras, whereas the lower teeth show similarities to those of $E$. stenonis (Burke et al., 2003). In the postcranial skeleton, the proportions of the limb bones are similar to those of hemiones but they are more slender (Eisenmann and Baryshnikov, 1994; Forstén, 1999; Burke et al., 2003; Orlando et al., 2006). The character states of particular dental traits in the various equid lineages are listed in Table 2.

\section{RESULTS}

\section{Size Distribution}

Histograms of measurements on single skeletal elements reveal the presence of two clearly defined size groups in the material (Appendix 9). For many measurements, there is no overlap between the two size groups, and in most of these cases, a clear gap separates the two groups. The variation between the groups is larger than the intraspecific variation observed in various extant and fossil equid species (van Asperen, in press). Most specimens can therefore be easily and reliably attributed to one of the two size groups. Overall, 176 specimens $(70.7 \%)$ fall in the small size group, while the large size group contains consistently lower numbers of specimens for each element $(n=37,14.9 \%)$. The remaining 36 specimens $(14.5 \%)$ cannot reliably be attributed to either size group. This category contains juvenile specimens $(n=12)$, which can in many cases tentatively be ascribed to one of the two size groups (nsmall=2, nlarge=9). Most other specimens of the indeterminable size group are fragmentary, or represent parts of the vertebral column $(n=14,5.6 \%)$. The EBK equid sample contains 12 cranial remains, including a number of nearly complete skulls. Three and possibly four skull fragments belong to a large equid, seven to a small equid, and one fragment is too small to conclusively attribute to either group. Similarly, of the 12 complete and fragmentary mandibles in the collection, 10 are of small size and two are of large size.

To establish the specific affinities of the two size groups, and to investigate the presence of disparate morphologies within the two size groups, the cranial remains and the longbones were subjected to further morphological analysis for each size group using scatterplots and log ratio diagrams.

\section{Systematic Palaeontology}

Family EQUIDAE Gray, 1821

Genus EQUUS Linnaeus, 1758

Type species Equus caballus Linnaeus, 1758, by original designation

Equus hydruntinus (Regalia, 1907)

Synonymy: initially named by Regalia (1907) as Equus (Asinus) hydruntinus based on material from the Italian site Castello, the species is now commonly known as Equus hydruntinus (see e.g., Alimen, 1946; Davis, 1980; Kuzmina, 1997; Orlando et al., 2006; Boulbes, 2009).

Material: cranium: nos. Ba2 384, Ba2 2570, Bc M1 (141), Bc M1 1655, Bc (m) 2073, Bc 2360, Bc 12; P4 no. Bb 41/12; $M 2$ no. Bb 40/31; M3: nos. Bc 2085, Bb 43/32; mandible: nos. Ba2 2483, Ba2 2023, Ba2 2024, Ba2 2065, Ba2 2343, Ba2 2483, Ba2 2483, Ba2 3334, Bb2 16, Bc 227 1666; m3 no. Bc 2044; atlas: nos. Ba 2068, Bc 1119, Bc 2200; axis: nos. Ba2 2067, Bc 2215, Bc 251 2407, Bc 259 2421; cervical vertebrae: nos. Bb 84, Bb 30/ 35, Bb 83, Bc 2086; thoracic vertebrae: nos. Ba2 2039, Ba2 2066, Bb 76, Bb77, Bb 78, Bb 79, Bb 80, Bb 87, Bb 92, Bb 94, Bb 30 35, Bc 1127, Bc F5 1158, Bc 1483, Bc 1490, Bc 1616, Bc 3 1860, Bc 2088, Bc 2194, Bc 2198, Bc 2206, Bc 2207, Bc 2a 2247, Bc 306 2376, Bc 299 2372, Bc 273 2374, Bc G5 2454, Bc G5 2455, Bc G5 2458, Bc G5 2460, Bc G5 2461, Bc G5 2462, Bc G5 2464; lumbar vertebrae: nos. Bb 86, Bc C3 1030, Bc 1642, Bc 74 1872, Bc 5 1873, Bc 73 1874, Bc 18175, Bc 2211; pelvis: nos. Ba2 2002 (both sides), Ba2 2040, Bb 
TABLE 2. Dental characteristics of different equid lineages (Alimen, 1946; Eisenmann, 1980, 1981, 2010; Eisenmann and Baryshnikov, 1994; Smit 1996; Baxter, 1998; Eisenmann and Mashkour, 1999; Burke et al., 2003; Orlando et al., 2006; Forstén, 1999).

\begin{tabular}{|c|c|c|c|c|c|}
\hline \multicolumn{6}{|c|}{ Upper cheek teeth } \\
\hline Trait & Sussemiones & $\begin{array}{c}\text { Equus } \\
\text { hydruntinus }\end{array}$ & $\begin{array}{c}\text { Caballoids (true } \\
\text { horses) }\end{array}$ & Zebroids (zebras) & $\begin{array}{c}\text { Stenonids (asses, } \\
\text { hemiones) }\end{array}$ \\
\hline Pli caballin & $\begin{array}{l}\text { Multiple and/or large } \\
\text { base, sometimes club- } \\
\text { shaped }\end{array}$ & $\begin{array}{l}\text { Infrequent, much } \\
\text { reduced }\end{array}$ & Frequent & Frequent & Infrequent \\
\hline Enamel & Often highly plicated & $\begin{array}{l}\text { Fossettes small and } \\
\text { simple }\end{array}$ & Plicated & Plicated & Simple \\
\hline Protocone & Very short & Triangular, short & Long, narrow & Triangular, short & Oval, short \\
\hline \multicolumn{6}{|c|}{ Lower cheek teeth } \\
\hline Trait & Sussemiones & $\begin{array}{c}\text { Equus } \\
\text { hydruntinus }\end{array}$ & $\begin{array}{c}\text { Caballoids (true } \\
\text { horses) }\end{array}$ & Zebroids (zebras) & $\begin{array}{c}\text { Stenonids (asses, } \\
\text { hemiones) }\end{array}$ \\
\hline First incisor & & $\begin{array}{l}\text { Often lacks } \\
\text { infundibulum }\end{array}$ & & & \\
\hline Ectostylid & $\begin{array}{l}\text { Present; sometimes } \\
\text { isolated }\end{array}$ & & Frequent & $\begin{array}{l}\text { Intermediate } \\
\text { frequency }\end{array}$ & Infrequent \\
\hline Protostylid & $\begin{array}{l}\text { Frequent on p2; } \\
\text { sometimes extremely } \\
\text { developed on p3-m3 }\end{array}$ & Absent on p2 & Infrequent & Infrequent & Infrequent \\
\hline Double knot & $\begin{array}{l}\text { Resembles hemiones; } \\
\text { elongated, sometimes } \\
\text { bilobated metaconid }\end{array}$ & $\begin{array}{l}\text { Metastylid can be } \\
\text { angular }\end{array}$ & Angular or triangular & Asymmetrical & Asymmetrical \\
\hline $\begin{array}{l}\text { Buccal wall of } \\
\text { protoconid and } \\
\text { hypoconid }\end{array}$ & & Rounded & Flat & Rounded & \\
\hline Lingual valley & Shallow & V-shaped & U-shaped & V-shaped & V-shaped \\
\hline Vestibular groove & $\begin{array}{l}\text { Frequently deep on } \\
\text { molars and some } \\
\text { premolars, but very } \\
\text { variable }\end{array}$ & $\begin{array}{l}\text { Deep, especially on } \\
\text { molars }\end{array}$ & Intermediate depth & $\begin{array}{l}\text { Deep, especially on } \\
\text { molars }\end{array}$ & Shallow \\
\hline
\end{tabular}

32/10, Bb 108, Bc 1147, Bc 1148, Bc G5 1235, Bc 1480, Bc 1482, Bc B4 34 2050, Bc 289 2379; sacrum: nos. Ba2 2062, Bc 2223; scapula: nos. Ba2 2589, Bb27/28, Bc 1598; humerus: nos. Ba2 2069, Ba2 3328, Bb 26/17, Bc B3 1317, Bc/m 1419, Bc 188 1822, Bc/m 2074; radius: nos. Ba2 1934, Ba2 2029, Ba2 2031, Ba2 3336, Bb 61, Bc C3 1023, Bc 1286, Bc 120 1444, Bc 1578, Bc 124 1713, Bc 2031; ulna: Ba2 1934, Ba2 2029, Ba2 3336, Bc 1286, Bc 2082, Bc 2103, Ba2 2031; metacarpals: nos. Ba2 3345, Bb 35/19, Bc 186 1443, Bc 371 1801, Bc/B4/50 2473; femur: nos. Bb 1/15, Bb 7/30, Bc A4 1008, Bc B5 1101, Bc B3 1284, Bc 145 1438, Bc 187 1439, Bc 1613, Bc (m) 2075; tibia: nos. Ba2 2030, Ba2 2333, Ba2 3311, Bb 17/22, Bc B3 1287, Bc 90 1440, Bc 1576, Bc 65 1692, Bc (m) 2076, Bc (m) 2077, Bc 30 2078, Bc (m) 2079; astragalus: nos. $\mathrm{Bb}(\mathrm{m})$ 2084, Bc M1
1659, Bc 2a 2018, Ba2 2052, Ba2 2061; calcaneum: nos. Ba2 2043, Ba2 2044; os naviculare: nos. Ba2 2752, Bc 356 1831; metatarsals: nos. Ba2 1753, Ba2 1915, Ba2 2060, Ba2 2038, Bb 22/ 20, Bc G5 1231, Bc A4 2003/2 1003, Bc 23 1442, Bc 372 1809; first phalanges: nos. Ba2 3341, Bb 53 (posterior), Bb 54 (anterior), Bb 55 (posterior), Bc G5 1229, Bc B3 1291, Bc 1899, Bc S 2245, Bc 2a 2259; second phalanges: nos. $\mathrm{Ba} 2$ 1928, $\mathrm{Bb}$ 205, Bb 207, Bc 388 1898; third phalanges: nos. Ba2 956, Ba2 2568, Bc 2239.

Further details of the material can be found in Appendix 1.

\section{Diagnosis and Description}

The size and morphological variation within the small size group are within that observed in other equid species (van Asperen, in press). There 

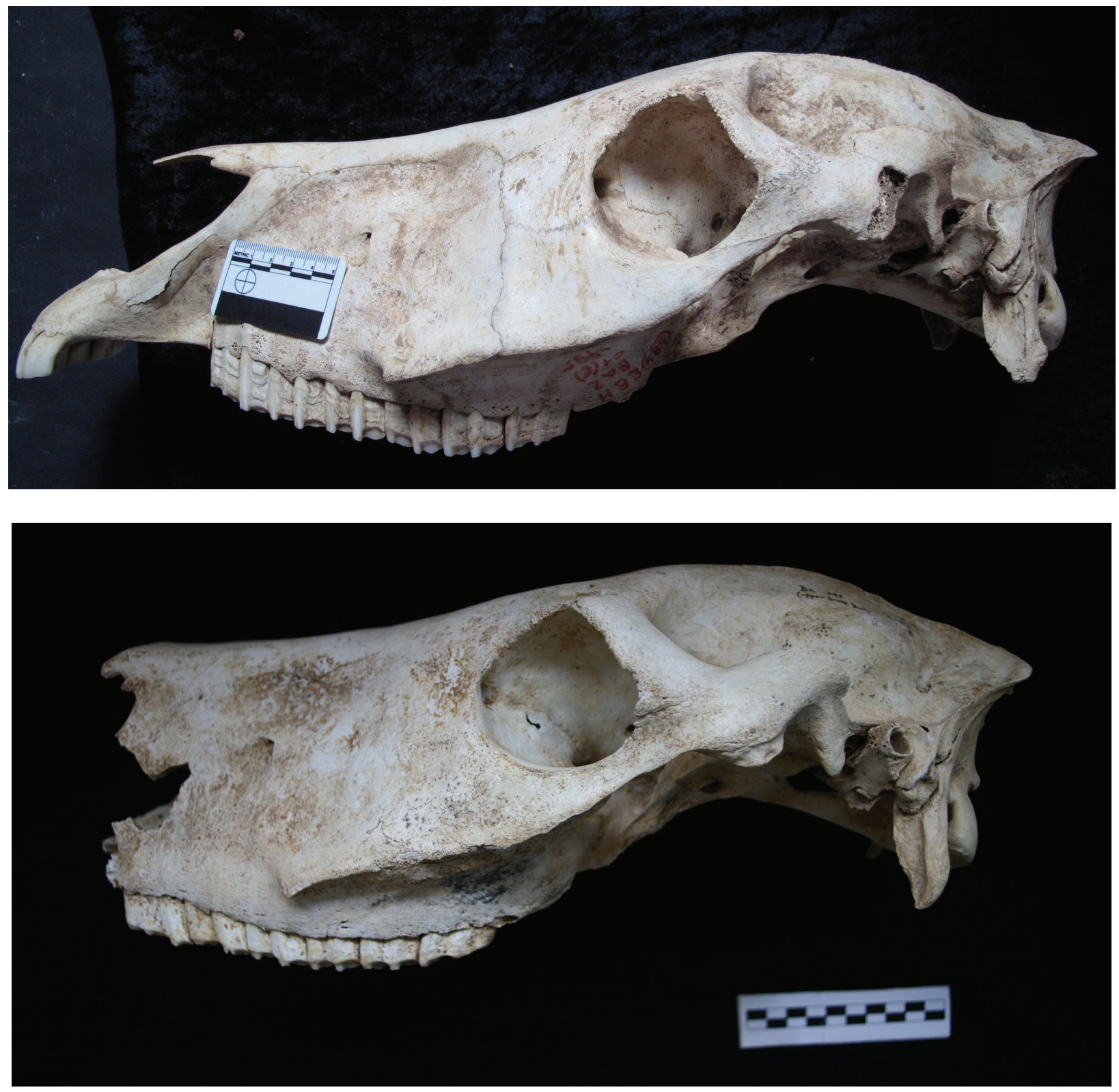

FIGURE 3.1. Skull no. Ba2 384 (photo E. van Asperen; scale in cm). FIGURE 3.2. Skull no. Bc 141 (photo P. Socha; scale in cm). FIGURE 3.3. Skull no. Bm001 (photo E. van Asperen; scale in mm). (Continued next page.)

are no clear differences in size and shape between remains from the different locations in the cave (Appendices 2, 5, 6, 7, 8). However, individual sample sizes per location are small, and conclusions regarding their homogeneity are therefore preliminary. In the following, the samples from locations $\mathrm{Ba}, \mathrm{Bb}$, and $\mathrm{Bc}$ are discussed jointly.

The skull no. Ba2 384 from the bottom of unit $\mathrm{H}$ at the $\mathrm{Ba}$ location (Figure 3.1) presents, apart from some damage to the left temporal bone and the right frontal bone, a complete skull. Although
Franck's Index (relative size of V3 to V4; Forstén, 1999; Eisenmann, 2006) falls within the caballoid range, with $\mathrm{V} 4$ being larger than $\mathrm{V} 3$, the Palatal Index (relative size of $\mathrm{V} 2-\mathrm{V} 5$ to $\mathrm{V} 3$; Eisenmann, 2006) does not (Appendix 2). A log ratio diagram shows that the specimen is smaller than skulls of Equus hemionus on most measurements (Appendix 2, Figure 4). The main morphological difference with the E. hemionus baseline of the graph is in the large palatal length (V2-V5) and muzzle breadth (V17) relative to muzzle length (V5), which is short. 


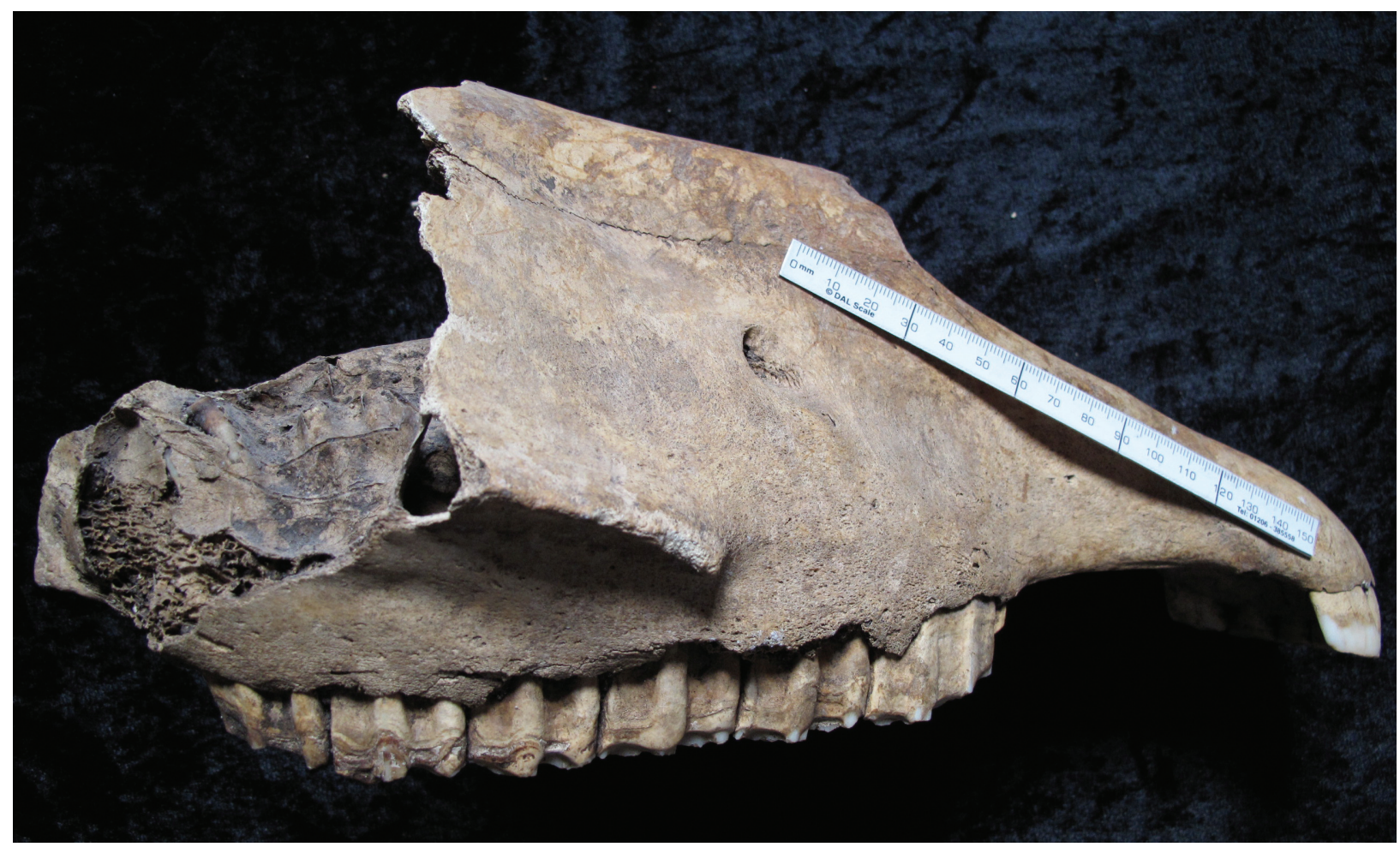

Figure 3 (continued).

A short but broad muzzle distinguishes hemiones from caballoids (Eisenmann, 1980; Burke et al., 2003; Orlando et al., 2006), and the EBK specimen possesses these characteristics in an extreme form. Specimen Bc 141 from the Bc location (Figure 3.2 ) is also virtually complete, missing only the nasal bone, premaxillary bone and the frontal part of the maxilla, which prevents an assessment of its muzzle shape. It is similar in size and morphology to the other small EBK specimen.

Overall, these specimens thus display stenonid rather than caballoid traits, and they differ morphologically from Equus hemionus skulls. Only few cranial remains of $E$. hydruntinus are known, including two skulls, one of which is nearly complete, from the Crimean Middle Palaeolithic site Kabazi II (Burke et al., 2003; Patou-Mathis and Chabai, 2003). Unfortunately, a significant number of the published measurements on these skulls are estimates from images or from damaged regions of the specimens (Burke et al., 2003). Besides these more complete remains, two other skull fragments are known from the site of Lunel-Viel. The fragments available for $E$. hydruntinus from Lunel-Viel belong to smaller-sized animals but are morphologically similar to the EBK specimens, although the muzzle is relatively shorter in the EBK material (Figure 4). Bonifay (1991) formulated the small- bodied subspecies $E$. hydruntinus minor based on the Lunel-Viel remains. The sparse data for the Kabazi II Equus hydruntinus skull show it belonged to a similar-sized individual as the EBK specimens. Most of the dental remains are embedded in the skulls or mandibles. Dental elements associated with the skulls of the small size group and a

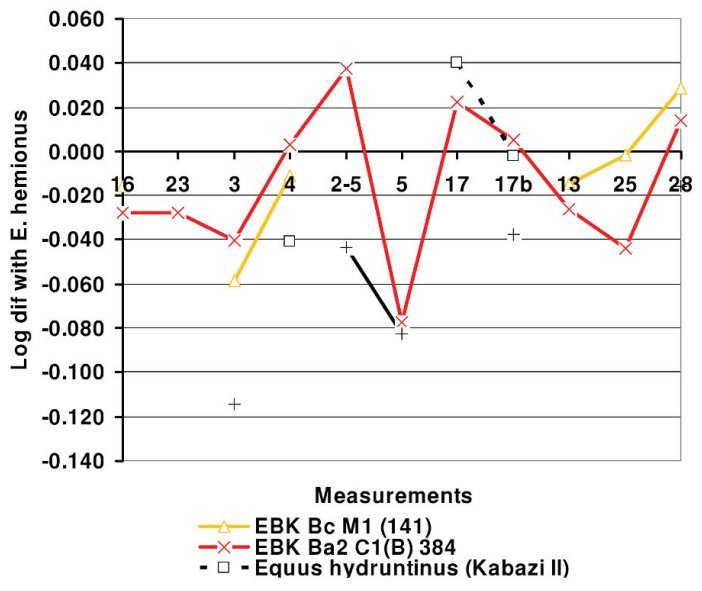

FIGURE 4. Log ratio diagram of measurements of the small EBK equid skulls compared with those of Equus hydruntinus. 
small number of isolated dental elements (Appendices 3,4$)$ fall within the size variation known for Equus hydruntinus. In the upper dentition, the length of the premolars and the lengths and widths of the molars also fall within the size variation of $E$. hemionus. In contrast, premolar width and protocone length of both premolars and molars are smaller than in this species and similar to those of $E$. hydruntinus. The upper dental elements in this size group generally have stenonid characteristics, with relatively simple fossettes with 2-3 enamel folds. A pli caballin is infrequently present (Eisenmann, 1980), and when present, it is weakly developed. In contrast with hemiones, the protocones are triangular. In the lower dentition, the small widths relative to lengths are reminiscent of $E$. hemionus, but still within the variation of $E$. hydruntinus. The double knot is asymmetrical with an angular metastylid, as in Equus hydruntinus. The lingual valleys are $\mathrm{V}$-shaped and vestibular grooves are deep on the molars, both stenonid traits. No teeth with sussemione characteristics are present.

The lengths of the longbones in the small size category group in the lower size range of Equus hemionus. Unfortunately, little comparative material is available for $E$. hydruntinus. The relative proportions of the limb bones are similar to those of $E$. hemionus and $E$. hydruntinus from Late Pleistocene Crimean sites (Figure 5.1). They tend to have more robust diaphyses (radius, femur and tibia $\mathrm{SD}$ ), although the proximal epiphyses are slender (Appendices 5, 6, 7, 8, 9, Figure 5.2).

A more detailed inspection of metapodial and first phalanx morphology using log ratio diagrams reveals clear morphological differences between the small-sized specimens from EBK and Equus hemionus (Figure 6.1-4). The EBK metapodials are more robust (V3, 4, 6, 7, 10 and 11), an important difference being the small proximal breadth, as in the various $E$. hydruntinus samples. The specimens are larger than the $E$. hydruntinus metapodials from Lunel-Viel, but similar in size and morphology to the $E$. hydruntinus material from Italian and Crimean Late Pleistocene sites, although with less relief on the distal epiphysis (V12-V14). One anterior first phalanx and two posterior first phalanges fall in this size group. They are morphologically similar to the E. hemionus baseline of the diagram in most respects. The relative size of V12 to V10 increases over the evolutionary history of the horse lineage (Dive and Eisenmann, 1991; van Asperen, 2009). Its large size in the EBK anterior phalanx could reflect the young geological age of the specimen, although the evolutionary trend has mainly been documented for caballoid horses over the Pleistocene and little is known about similar trends in other Pleistocene equids. However, this trend cannot be observed in the posterior first phalanges. A long trigonum phalangis, a further derived feature (Dive and Eisenmann, 1991), characterises both the anterior and posterior first phalanges.

Whenever this could be assessed, skeletal elements in the small size group show stenonid characteristics. Furthermore, the size and morphology of these specimens is in accordance with a specific attribution to Equus hydruntinus, while clear differences with Equus hemionus were found. The material is therefore determined as Equus hydruntinus.

\section{cf. Equus hydruntinus}

Material: thoracic vertebrae: nos. Bc 77 1861, Bc 88 1867; femur no. $\mathrm{Bb} 65$; os tarsale tertium no. Ba2 2057.

Further details of the material can be found in Appendix 1.

\section{Diagnosis and Description}

The thoracic vertebrae belong to subadult individuals. The juvenile femur and the os tarsale tertium represent fragments. Although their small size seems to point to an affinity with the Equus hydruntinus material from the cave, they cannot be conclusively attributed to this species due to the absence of specific characteristics.

Equus ferus latipes (Gromova, 1949)

Synonymy: this subspecies was originally formulated as Equus caballus latipes based on material from the site Kostenki, Russia (Gromova, 1949). Although the material has subsequently been given specific status by some authors (e.g., Eisenmann, 1991), levels of ecomorphological variation documented for caballoid equids (van Asperen, 2010) indicate that subspecific status is more appropriate. Following the guidelines of the International Commission on Zoological Nomenclature (ICZN 2003), which state that the species name Equus caballus should only be used for domesticated animals, we here follow Cramer (2002) and van Asperen (in press) and regard this material as representing a subspecies of Equus ferus.

1949 Equus caballus latipes; Gromova

1949 Equus caballus chosaricus; Gromova

1966 Equus taubachensis; Vangenheim

1968 Equus caballus orientalis; Russanov 

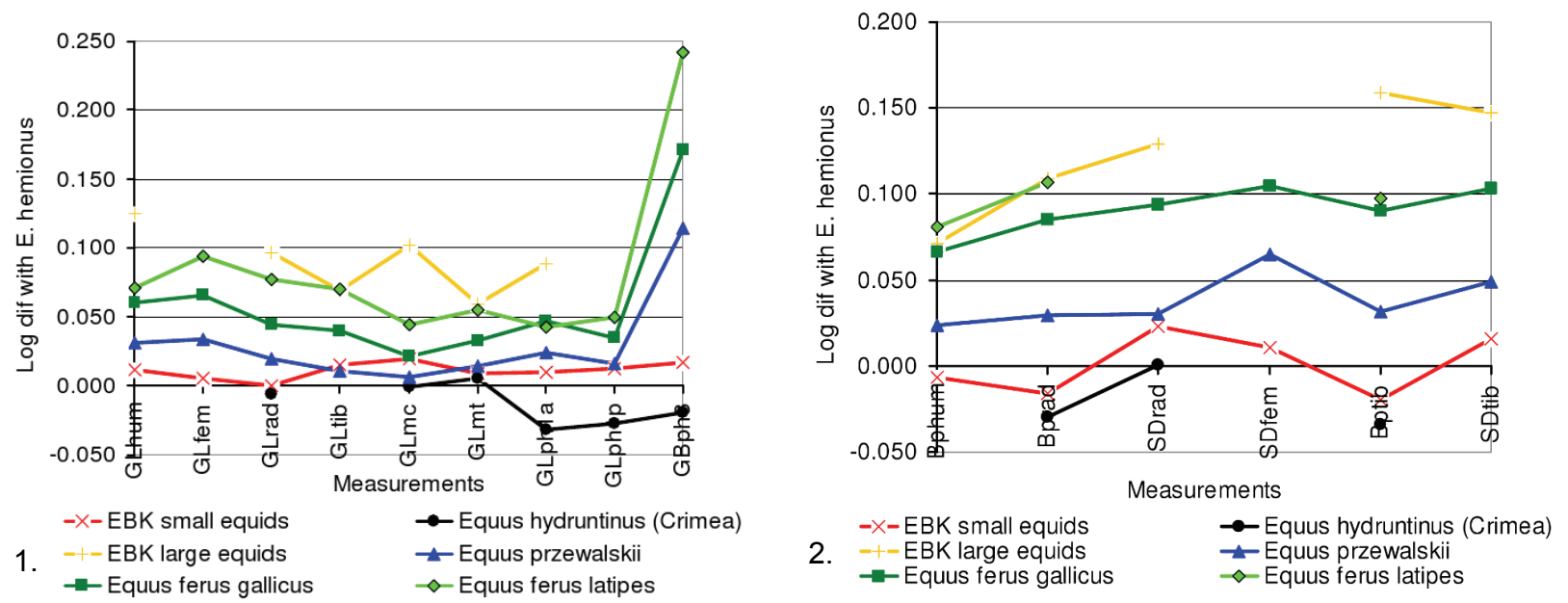

FIGURE 5.1. Log ratio diagram of measurements of the EBK equid longbones compared with those of extant and extinct equids; hum=humerus, fem=femur, rad=radius, tib=tibia, $\mathrm{mc}=$ metacarpus, $\mathrm{mt}=$ =metatarsus, $\mathrm{ph} 1 \mathrm{a}=$ =anterior first phalanx, ph1p=posterior first phalanx, ph3=third phalanx; GL=greatest length, GB=greatest breadth. FIGURE 5.2. Log ratio diagram of measurements of the EBK equid longbones compared with those of extant and extinct equids; hum=humerus, rad=radius, fem=femur, tib=tibia; $B p=$ proximal breadth, $S D=s m a l l e s t$ breadth of the diaphysis.

\section{Equus remagensis; Nobis}

1995 Equus germanicus; Forstén

\section{Equus (Equus) latipes; Kuzmina}

Holotype: third anterior phalanx from the site Kostenki 4, Russia, stored in the Zoological Institute of the Russian Academy of Sciences in St. Petersburg (no. 20664(76)).

Material: cranium and cranial fragments: nos. $\mathrm{Bb}$ 96, Bc 38, Bm001; P3/4 no. Bb300; M3 no. Bb 44/ 27; mandibles and mandible fragments: nos. Bb3 112, Bb 112; cervical vertebrae: nos. Ba2 2070, Bb 91, Bc 2196; thoracic vertebrae: nos. Bb 81, Bb93; lumbar vertebrae: nos. $\mathrm{Bb} 82, \mathrm{Bb} 90$; pelvis no. $\mathrm{Bc}$ F5 2134; humerus: nos. Bc 146 2426, Bc 146 2427; radius: nos. $\mathrm{Bb} 62$, $\mathrm{Bb} 67$; ulna: nos. $\mathrm{Bb} 97$, Bb 100; metacarpals: nos. Bb3 11 34, Bc F5 1151, Bc 150 1720, Bc 87 1804, Bc S 145 2244; femur no. Bc 1579, tibia no. $\mathrm{Bb}(\mathrm{m}) 3$; astragalus: nos. Bc 64 1441, Bc 1622; calcaneum no. Bb 13/18; os naviculare no. $\mathrm{Bb} 136$; metatarsals: nos. $\mathrm{Bc}(\mathrm{m})$ $2080, \mathrm{Bc}(\mathrm{m})$ 2081; first phalanges: nos. Bb 33/21 (anterior), Bc $S$ 2246; second phalanges: nos. Bb 9/29, Bb 1730.

Further details of the material can be found in Appendix 1.

\section{Diagnosis and Description}

Although sample sizes are very small, specimens from the different locations in the cave are of similar size and shape (Appendices 5-6). Material from the locations $\mathrm{Ba}, \mathrm{Bb}$, and $\mathrm{Bc}$ is therefore discussed jointly.

Skull Bm001, of which the maxilla, premaxillary bone, and the posterior part of the nasal bone are preserved (Figure 3.3), falls within the large size group. The specimen belongs to a young male whose canines are erupting. The right M3 (the left M3 is not preserved) is in an early stage of wear, indicating that the individual was four to five years old at death (Silver, 1969). The specimen is smaller than the skulls of Equus ferus gallicus, but has a relatively long muzzle (V5, Figure 7). Unfortunately, comparative data for Equus ferus latipes are too scanty to enable a direct comparison.

A limited number of dental elements belong in the large size group, including those embedded in skull Bm001. The sample also contains three mandibles. The upper dental elements (Appendix 3) cluster within the lower range of the variation for $E$. ferus latipes, E. ferus gallicus and E. przewalskii. The lower dentition, by contrast, tends to fall in the upper part of or beyond the variation for $E$. ferus gallicus, but still well within the variation for $E$. ferus latipes and $E$. przewalskii (Appendix 4). Widths appear to be relatively small, contrary to those of E. przewalskii. These tooth rows and a number of isolated dental elements have caballoid characteristics. The upper teeth have relatively complex fossettes with 3-5 enamel folds and elongated protocones. A pli caballin is frequently present, and when present is weakly to strongly developed. The 

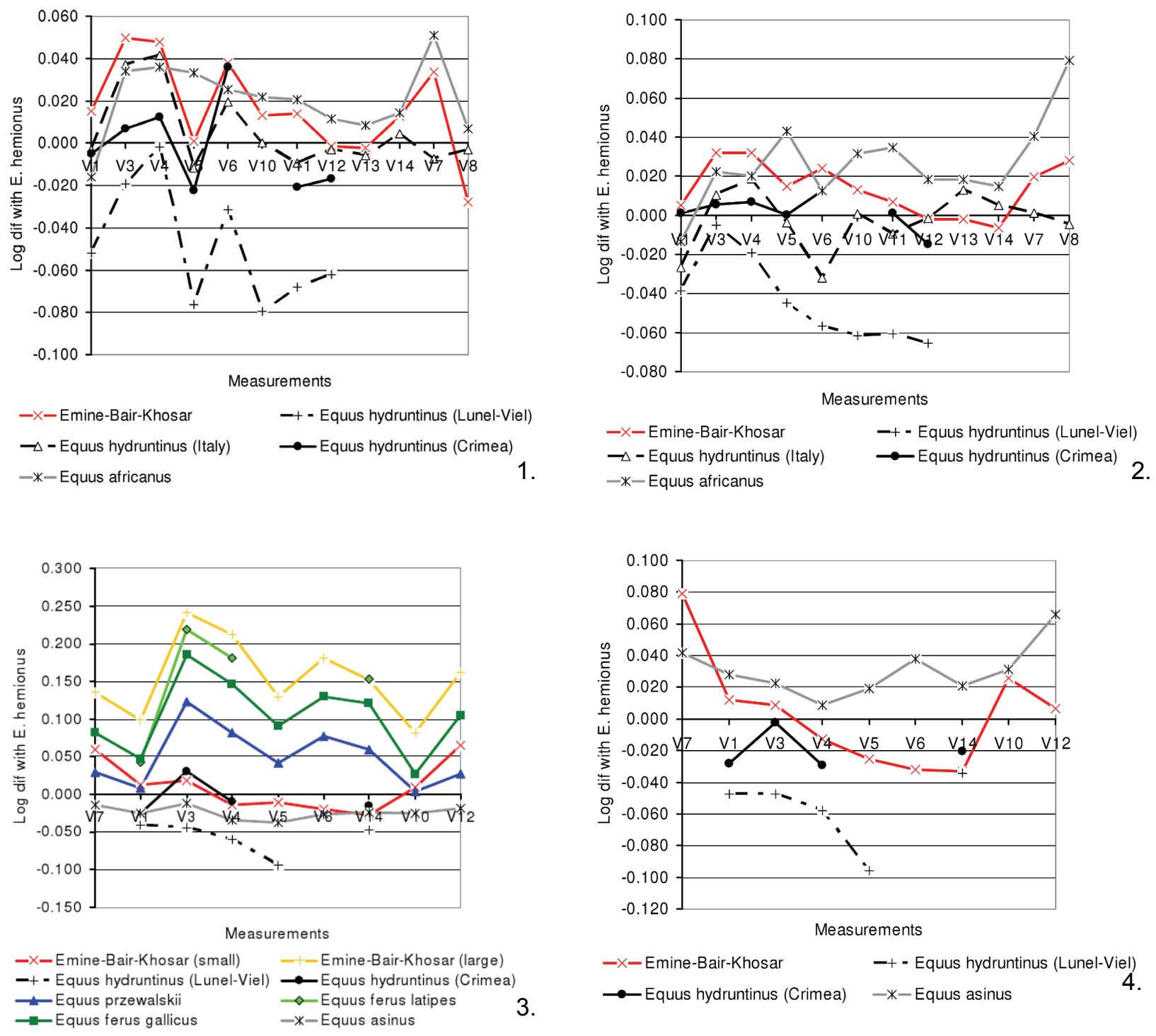

FIGURE 6.1. Log ratio diagram of measurements of the small EBK equid metacarpals compared with those of Equus hemionus, several E. hydruntinus samples and E. africanus. FIGURE 6.2. Log ratio diagram of measurements of the small EBK equid metatarsals compared with those of Equus hemionus, several E. hydruntinus samples and E. africanus. FIGURE 6.3. Log ratio diagram of measurements of the EBK equid anterior first phalanges compared with those of Equus hemionus, several E. hydruntinus samples and E. asinus. FIGURE 6.4. Log ratio diagram of measurements of the EBK equid posterior first phalanges compared with those of Equus hemionus, several $E$. hydruntinus samples and $E$. asinus.

lower dental elements have a U-shaped lingual valley and a shallow to medium deep lingual groove.

Longbones in the large size group are generally longer than those of $E$. ferus gallicus, similar to those of E. ferus latipes or even longer (Appendices 5, 6, 7, Figure 5.1). Especially the front limb (humerus, radius, metacarpus, anterior first phalanx) is relatively long. These bones are less than (humerus, radius) or similarly (tibia) robust as in
Equus ferus gallicus and E. ferus latipes (Figure 5.2).

From the log ratio diagrams it can be seen that the large-sized EBK metacarpals are larger than those of E. ferus gallicus, with a relatively slender diaphysis (V3 and $\mathrm{V} 4$ ) and low relief on the distal epiphysis (V12-14, Figure 8.1). The EBK metatarsals are similar in size and morphology to those of E. ferus latipes, with a deep proximal epiphysis (V6, Figure 8.2). The single anterior first 


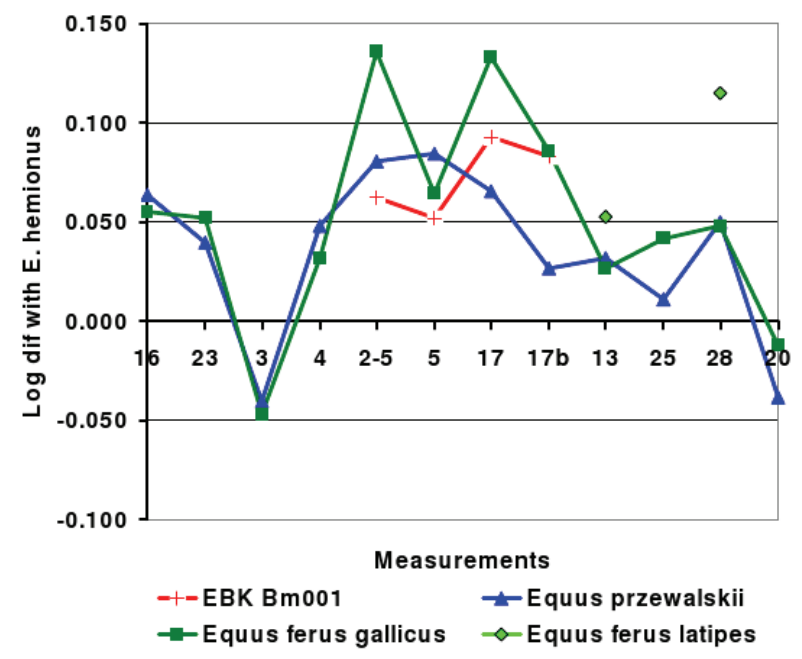

FIGURE 7. Log ratio diagram of measurements of the large EBK equid skulls compared with those of Equus przewalskii, Equus ferus gallicus and Equus ferus latipes.

phalanx in the large size category is morphologically similar but larger than the comparative caballoid samples (Figure 6.3). V12 is relatively large, which is a morphologically derived feature, typical for Late Pleistocene equids (Dive and Eisenmann, 1991).

From the size and shape of the large-sized equid remains, it is clear that this sample represents a caballoid equid. The specimens are similar in size to Late Pleistocene caballoid remains, and clearly differ in size and morphology from Equus przewalskii specimens. In several respects, the EBK remains are more similar to Equus ferus latipes than to Equus ferus gallicus. The specimens are therefore attributed to Equus ferus latipes.

\section{cf. Equus ferus latipes}

Material: cervical vertebrae: nos. Bc B4/6a 1582 , Bc 277 2409, Bc 344 2410, Bc B4 1042, Bc 1760, Bc 2209, Bc 321 2375; thoracic vertebra no. Bc B4 1043; pelvis no. Bc 24A 2399; ulna no. Bc 57 1449; femur no. Bc 2378; os tarsale tertium no. Bb 77 206.

Further details of the material can be found in Appendix 1.

\section{Diagnosis and Description}

Although their large size seems to indicate a determination of Equus ferus latipes, these fossils cannot be conclusively attributed to this species due to the absence of specific characteristics. This is due to the juvenile (5 cervical vertebrae, thoracic vertebra, ulna), subadult (2 cervical vertebrae), or fragmentary (pelvis, femur, os tarsale tertium) character of the material.

Equidae gen. et sp. indet.

Material: cranial fragment no. $\mathrm{Bb} / \mathrm{m} 1$; lumbar vertebrae: nos. Bb 85, Bc 1618; costa no. Bb 33; sacrum no. Bc 348 1826; scapula: nos. Ba2 2021, Bb 43, Bc 67 1448, Bc 296 2377, Bc 283 2376, Ba2 1947, Ba2 2042; os carpale tertium no. C1(W); os capitatum no. Bc 1146; os pyramidale no. Bc G5 1230; os scaphoideum no. Bb 143; patella: nos. Bc A4 1009, Bc 312 1789, Bc 2228; os malleolare no. Bc B4 1048.

Further details of the material can be found in Appendix 1.

\section{Diagnosis and Description}

These specimens clearly belong to an equid. However, due to their juvenile (lumbar vertebrae, sacrum) or fragmentary (cranial fragment, costa) state, it is not possible to determine them to lineage level. The morphology of the scapulae is unclear: in some of their dimensions they resemble the Equus hydruntinus material from the site, but other dimensions are clearly larger. Since there is no complete scapula of Equus ferus latipes available from the site, their specific affiliation cannot be determined clearly. For the carpalia, patella, and os malleolare, no comparative material could be found in the literature for Equus hydruntinus. Their specific affiliation is therefore not stated here. 

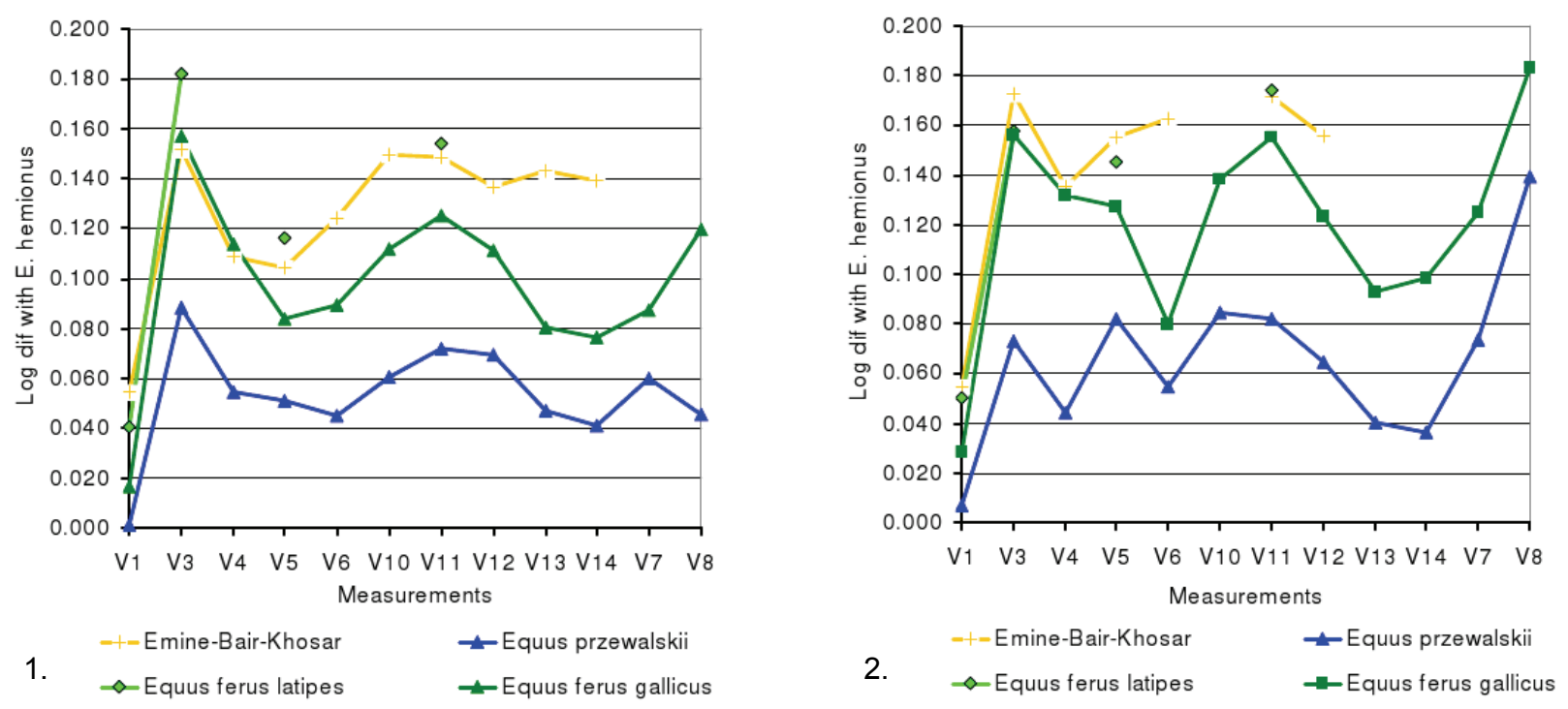

FIGURE 8.1. Log ratio diagram of measurements of the large EBK equid metacarpals compared with those of Equus przewalskii, E. ferus latipes and E. ferus gallicus. FIGURE 8.2. Log ratio diagram of measurements of the large EBK equid metatarsals compared with those of Equus przewalskii, E. ferus latipes and E. ferus gallicus.

\section{DISCUSSION}

The earliest known fossils of Equus hydruntinus, also known as the European wild ass, originate from Acheulean sites in the Near East (Nadaouiyeh Aïn Askar: Reynaud Savioz and Morel, 2005; C-Spring, Azraq: Clutton-Brock, 1989). The earliest finds in Europe consist of isolated dental elements from the British Hoxnian site Swanscombe. The oldest European assemblage with both cranial and postcranial remains was recovered from the French late Middle Pleistocene site Lunel-Viel, which is thought to date from OIS 9 (Boulbes, 2009). Remains of the species are found throughout the late Middle and Late Pleistocene in Europe and the Near East (Orlando et al., 2006). The fossils display body size fluctuations, leading Bonifay (1991) to attribute the small-sized, slender specimens from Lunel-Viel to the subspecies Equus hydruntinus minor. Eisenmann and Baryshnikov (1994) noted that several sites (e.g., Binagady, Achenheim Lower Old Loess, Petralona) have produced similar small, rather slender remains. Other sites (e.g., Roterberg) are characterised by longer metapodials, although the dental elements remain of small size. By the end of the Pleistocene, the species became extinct in Western Europe (Stewart, 2007). In Italy, Romania, and Ukraine, it survived into the Holocene (Willms, 1989; Baxter, 1998). The youngest Equus hydruntinus fossils have been documented from Iron Age sites in Iran (Orlando et al., 2006). A possible $17^{\text {th }}$ century specimen of the species from Portugal is genetically and morphologically similar to donkeys, and may therefore not be a specimen of the species (Orlando et al., 2009).

Although recent DNA studies have clarified some of the problems surrounding the systematic position and evolutionary history of extant and extinct equid species (Orlando et al., 2006, 2009; Weinstock et al., 2005), there is still considerable debate concerning the relationship of Equus hydruntinus to other equid lineages. Because of the equivocal morphological signature of the species, close relationships with extant zebras, asses, and primitive equid lineages have been suggested (Stehlin and Graziosi, 1935; Davis, 1980; Forstén, 1986; Forstén and Ziegler, 1995). Analyses of mitochondrial DNA, in contrast, indicate that the species is genetically closely similar to hemiones (Asian wild asses; Orlando et al., 2006, 2009). The specimens analysed with these techniques fall within the variation observed within extant hemiones, and therefore a separate specific status for the species may not be warranted. However, since only short strands of mtDNA from a small number of individuals have been analysed so far, and intraspecific differentiation in mtDNA sequences is very limited within the hemione clade, the results are preliminary (Orlando et al., 2006, 2009). Although some of the morphological traits that are considered to be characteristic for Equus hydruntinus also occur in hemione species (Orlando et al., 2006), separate specific status is upheld here since 
in most cases Equus hydruntinus can be morphologically differentiated from hemione species (Eisenmann and Mashkour, 1999). The EmineBair-Khosar fossils form a case in point, illustrating the morphological differentiation that can be observed between Equus hemionus and $E$. hydruntinus in both cranial and postcranial skeletal remains.

Given the limited information available so far on Equus hydruntinus cranial morphology, the presence of two virtually complete skulls of $E$. hydruntinus in the EBK collection is highly significant and has much to contribute to our knowledge of this enigmatic Pleistocene species. The very short muzzle of the complete EBK skull is striking. Short muzzle length has been hypothesised to be an adaptation to cold climatic conditions (Eisenmann et al., 1985). This is in accordance with the dating for the EBK site in the Last Glacial, and the morphological contrast with E. hemionus, an animal that lives in hot, dry environments, is thus not surprising. The small size of the dental elements and their stenonid traits are compatible with a determination as $E$. hydruntinus. The simple enamel bands, with few folds, are indicative of a hard diet (Eisenmann, 2010).

Contrary to previous findings (Eisenmann and Baryshnikov, 1994; Forstén, 1999; Burke et al., 2003; Orlando et al., 2006), the EBK longbones attributed to Equus hydruntinus were found to be more robust than those of $E$. hemionus. Equids are more robust in cooler environments (van Asperen, 2010). The robusticity of the limb bones of the Emine-Bair-Khosar E. hydruntinus is thus in accordance with the climatic conditions postulated for the Late Pleistocene of the site (Vremir and Ridush, 2005). The metapodials are morphologically similar to previously published specimens of E. hydruntinus. Intra-specific variation in the development of the distal epiphysis, as occurs between the EBK sample and other $E$. hydruntinus samples, has also been observed in caballoid equids, where no clear relationship to specific environmental or behavioural patterns could be traced (van Asperen, 2009).

Generally, E. hydruntinus is found in steppic assemblages, indicating a preference for dry environments. There are some indications that the species had a limited tolerance for cold climatic conditions. During the Late Pleistocene it is found in Western Europe during the less severe cold periods (Eisenmann and Baryshnikov, 1994; Stewart, 2007; Markova et al., 2010). This preference for temperate, dry environments is also reflected in the southward retreat of E. hydruntinus in Europe over the course of OIS 3, when the climate was deteriorating towards the Last Glacial Maximum (Stewart, 2007). Its presence in the EBK faunal assemblage is in accordance with the temperate to cool and dry steppic character of the fauna (Vremir and Ridush, 2005).

The EBK caballoid horse remains belong to Equus ferus latipes, although the single preserved skull is rather small. Its relatively long muzzle may indicate that climatic conditions were warmer than in Western Europe (Markova, 2011). The EBK longbones are clearly distinguishable from the Western European ecotype Equus ferus gallicus. In caballoid horses, a combination of small size and relative robusticity are characteristic of animals living in cold, unproductive environments (van Asperen, 2010). In comparison with the western European glacial climate, the Crimean climate seems to have been more suitable for caballoid horses, enabling them to grow to larger body size, especially in the less severe climatic conditions of OIS 3 and the more temperate climate during the deposition of the Bb sediments (Spassov and lliev, 1997). Similar to the EBK Equus hydruntinus remains, the relief on the distal epiphyses of the metapodials is relatively low in the caballoid specimens.

The EBK Equus hydruntinus and E. ferus latipes fossils co-occur in the $\mathrm{Ba}, \mathrm{Bb}$, and $\mathrm{Bc}$ locations in the cave. All material accumulated at the $\mathrm{Bb}$ site is thought to be contemporaneous. The $\mathrm{Ba}$ and $\mathrm{Bc}$ accumulations cover a larger timespan. However, the single, large-sized specimen known from the $\mathrm{Ba}$ location, cervical vertebrae no. Ba2 2070, comes from unit $\mathrm{H}$, from which several stenonid specimens were also recovered (such as mandible no. Ba2 2065, humerus no. Ba2 2069, radius nos. Ba2 2029 and Ba2 2031, ulna no. Ba2 2029, tibia no. Ba2 2030, metatarsals nos. Ba2 2038 and Ba2 2065 , and several smaller bones). Co-occurrence of the two species at this site is therefore likely. The largest number of Equus hydruntinus remains comes from the $\mathrm{Ba}$ and $\mathrm{Bc}$ locations, whereas the Equus ferus latipes specimens are concentrated in the $\mathrm{Bb}$ and $\mathrm{Bc}$ locations. However, as mentioned earlier, at all three locations Equus hydruntinus remains outnumber Equus ferus latipes remains (Appendix 1).

Equus hydruntinus is regularly found in association with a larger, caballoid horse, for example at the sites Swanscombe (UK) and Wallertheim (Germany; Gaudzinski, 1995). Eisenmann and Mashkour (1999) documented the co-occurrence of $E$. 
hydruntinus with a small-sized caballoid horse and a medium-sized hemione at the site Binagady in Azerbaidjan. At a different stratigraphic level of the same site, E. hemionus co-occurs with a smallsized hemione. A similar pattern can be observed in $E$. altidens, the possible ancestor of $E$. hydruntinus, which is usually found alongside larger-bodied stenonid horses such as E. major or E. suessenbornensis (Forstén, 1999). This indicates ecological differentiation within the equid family. A study of Asiatic wild asses and Przewalski's horses in the Bukhara Breeding Centre in Uzbekistan showed that these species of stenonid and caballoid equids could range over the same area without experiencing strong competition, due to differences in resource use (Bahloul et al., 2001). It is therefore no surprise that at EBK Equus hydruntinus occurs alongside a large, caballoid horse.

The low number of juvenile specimens in the equid assemblage $(4.8 \%)$ is striking. This underrepresentation of young animals is unlikely to be due to taphonomic factors, since the cave environment provided excellent chances for preservation, as is obvious from the well-preserved reptile and bird assemblages from the site (Vremir and Ridush, 2005). Assemblages of other large herbivores (deer, bovids, rhinoceroses) from the cave are dominated by juvenile remains.

Caballoid horses form two basic groups: harem groups consisting of one or two stallions and several mares with their foals, and bachelor groups made up of non-breeding males (Klingel, 1975; Linklater et al., 2000). In dry environments, the harem groups can be territorial (Bahloul et al., 2001). Generally, home range quality is lower for the bachelor bands than for the harem groups (Guthrie, 2001), but both groups tend to stay within 5-7 km of the nearest water source (Bahloul et al., 2001). The social system of Asiatic wild asses is flexible and varies with environmental factors, but often the males are territorial. They are better adapted to dry conditions, and therefore have larger home ranges that include areas further away from water sources (Bahloul et al., 2001). Equids have an annual reproductive cycle, with foaling usually taking place between late winter and early summer (Bahloul et al., 2001; McDonnell, 2005). In dry environments, reproduction in stenonid and zebroid equids has been observed to be correlated with periods of rainfall (Klingel, 1975). These species often migrate seasonally (Klingel, 1975; Bahloul et al., 2001). Seasonal migration has been postulated for Equus hydruntinus (Burke, 2006).
The Chatyrdag plateau with its extensive karstic features will have provided ample shelter, and its steppic vegetation was an abundant source of food in summer. Although there are no water sources on the plateau itself, there are many springs and a river in the foothills of the plateau. In winter, the plateau is often covered in snow, and the EBK pothole is located at a spot where windblown snow tends to accumulate at the edge of the plateau. One possible way in which the animals could have fallen into the cave is by the snow covering the pit collapsing under their weight after treading on it. This scenario could also explain the fact that animals of several species seem to have fallen into the cave in pairs.

The underrepresentation of juvenile remains could indicate that the Chatyrdag plateau was mainly frequented by bachelor herds, while the harem groups were confined to the more sheltered ravines and foothills near water sources. Since horses show very little sexual dimorphism (van Asperen, in press), it is difficult to establish whether the equid assemblages are dominated by males. However, the well-preserved caballoid skull belonged to a young male, old enough to have dispersed from his natal harem band but probably too young to be the dominant stallion of a harem band (Boyd and Keiper, 2005). The fact that remains of Equus hydruntinus outnumber those of Equus ferus latipes are also in accordance with the dry character of the plateau. The plateau seems to have been visited only occasionally by Equus ferus latipes, whilst it can be hypothesised that it was part of the home range of bachelor groups of Equus hydruntinus (Burke et al., 2008).

\section{CONCLUSION}

As previously documented for various European and Near Eastern Pleistocene and Holocene sites, the Emine-Bair-Khosar equid assemblage witnesses the co-occurrence of a stenonid and a caballoid horse. Overall the small-sized stenonid equid, Equus hydruntinus, is morphologically similar to Equus hemionus, but it clearly differs from this species in several important respects. Although genetic differentiation between the two species is thought to be limited (Orlando et al., 2006, 2009), separate specific status is upheld here. Large intra-specific adaptive variability has been shown to characterise another group of Pleistocene equids (van Asperen, 2010). Further research may likewise show that Equus hydruntinus is a now extinct ecotype of Equus hemionus, with important consequences for the specific affini- 
ties of Pleistocene stenonid fossils. The short muzzle and robust limb bones of the EBK specimens are certainly in accordance with an adaptation to cold, but dry climatic conditions. The Chatyrdag plateau was regularly frequented by bachelor groups of the species.

The large-sized caballoid equid belongs to the Late Pleistocene ecotype Equus ferus latipes. Its postcranial morphology indicates a clear continuity with the Middle and Late Pleistocene caballoid Equus ferus lineage of Europe and West-Asia (Eisenmann, 1991; Kuzmina, 1997; van Asperen, 2010). A comparison with the contemporaneous Western European ecotype Equus ferus gallicus reveals that adaptive morphological variations between different climatic regions follow similar patterns as in late Middle Pleistocene caballoids (van Asperen, 2010). Being adapted to cold conditions, the Late Pleistocene caballoids are relatively small-sized due to a shortage of nutritious resources (Forstén, 1991; van Asperen, 2010). However, more favourable climatic conditions in the Crimean peninsula enabled the EBK caballoids to grow larger, as well as being more slender due to somewhat higher temperatures, than their Western European counterparts (Spassov and Iliev, 1997). Although bachelor groups of the species occasionally utilised the resources on the Chatyrdag plateau, the core home ranges of the species were located elsewhere, possibly in the foot hills where water sources are more abundant.

The karstic caves of the Crimean peninsula are a rich source of varied vertebrate assemblages. Since many of the fossil remains recovered from these sites show excellent preservation, these assemblages have much potential to increase our knowledge of the vertebrate fauna of this biogeographically important area. Analysis of DNA has already shed light on the biogeography of Late Pleistocene red deer from the area (Stankovic et al., 2011), and this analysis could be extended to other species. This could be particularly significant when steppic species are targeted whose recent population history is characterised by repeated expansions from Central Asia into Europe. Much is still unknown about the details and dynamics of these environmentally driven range changes. Fossils from the Crimean peninsula, with its position at the junction of the European and Asian faunal provinces, can be expected to produce crucial information regarding these faunal processes. Moreover, the analysis of fossils belonging to particular vertebrate lineages is a powerful tool to investigate the extent of, and patterns in, morpho- logical variation in these animal groups, leading to a better understanding of biological diversity and its origins.

\section{ACKNOWLEDGMENTS}

We thank A. Nadachowski and T.P. O'Connor, as well as two anonymous referees, for their comments upon an earlier version of this paper, which helped us to improve the paper. We are grateful to the Centre of Speleotourism "Onix-Tur" and its director A. Kozlov for their longstanding support of field investigations in the EBK Cave and for their help during fieldwork seasons. P. Socha took the photos of the equids remains. This work was supported by grant no. 1018/S/IZ/09 (Department of Palaeozoology, Wrocław University) and by the European Commission under the Marie Curie Actions of the Sixth (PALAEO, MEST-CT-2005020601) and Seventh (PERG07-GA-2010-268242) Framework Programmes.

\section{REFERENCES}

Alimen, H. 1946. Remarques sur Equus hydruntinus Regalia. Bulletin de la Société Géologique de France, Série 5, Tome 16:585-595.

Bahloul, K., Pereladova, O.B., Soldatova, N., Fisenko, G., Sidorenko, E., and Sempéré, A.J. 2001. Social organization and dispersion of introduced kulans (Equus hemionus kulan) and Przewalski horses (Equus przewalski) in the Bukhara Reserve, Uzbekistan. Journal of Arid Environments, 47:309-323.

Baxter, I.L. 1998. Species identification of equids from Western European archaeological deposits: methodologies, techniques and problems, p. 3-17. In Anderson, S. (ed.), Current and recent research in osteoarchaeology, Proceedings of the Third Meeting of the Osteoarchaeology Research Group. Oxbow, Oxford.

Bignon, O. 2003. Diversité et exploitation des équidés au Tardiglaciaire en Europe occidentale, Implications pour les stratégies de subsistence et les modes de vie au Magdalénien et à l'Azilien ancien du Bassin parisien. Unpublished PhD thesis, Université Paris10, Nanterre, France.

Bondar, K.M. and Ridush, B.T. 2009. Record of paleoclimatic changes during Holocene - Upper Pleistocene in non-cemented sediments from Emine-Bair-Khosar cave by magnetic measurements. Speleology and Karstology, 2:70-76. (in Russian with English summary)

Bonifay, M.-F. 1991. Equus hydruntinus Regalia minor n.ssp. from the caves of Lunel-Viel (Herault, France), p. 178-216. In Meadow, R.H. and Uerpmann, H.-P. (eds.), Equids in the Ancient World, Volume II. Dr. Ludwig Reichert Verlag, Wiesbaden. 
Boulbes, N. 2009. Étude compare de la denture d'Equus hydruntinus (Mammalia, Perissodactyla) dans le Sud-Est de la France. Implications biogéographiques et biostratigraphiques. Quaternaire, 20:449-465.

Boyd, L. and Keiper, R. 2005. Behavioural ecology of feral horses, p. 55-82. In Mills, D.S. and McDonnell, S.M. (eds.), The domestic Horse, the Evolution, Development and Management of Its Behaviour. Cambridge University Press, Cambridge.

Burke, A. 2006. Palaeoethology as an archaeological tool: a model for the social and spatial behaviour of E. hydruntinus, p. 62-69. In Mashkour, M. (ed.), Equids in time and space, Papers in honour of Véra Eisenmann, Proceedings of the $9^{\text {th }}$ Conference of the International Council of Archaeozoology, Durham, August 2002. Oxbow, Oxford.

Burke, A., Eisenmann, V., and Ambler, G.K. 2003. The systematic position of Equus hydruntinus, an extinct species of Pleistocene equid. Quaternary Research, 59:459-469.

Burke, A., Ebert, D., Cardille, J., and Dauth, D. 2008. Paleoethology as a tool for the development of archaeological models of land-use: the Crimean Middle Palaeolithic. Journal of Archaeological Science, 35:894-904.

Cardoso, J.L. and Eisenmann, V. 1989. Equus caballus antunesi, nouvelle sous-espèce quaternaire du Portugal. Palaeovertebrata, 19:47-72.

Clutton-Brock, J. 1989. A re-consideration of the fossil fauna from C-Spring, Azraq, p. 391-397. In Copeland, L. and Hours, F. (eds.), The hammer on the rock: studies on the early Paleolithic of Azraq, Jordan, BAR international series 540. Archaeopress, Oxford.

Cramer, B. 2002. Morphometrische Untersuchungen an quartären Pferden in Mitteleuropa. Unpublished PhD thesis, Eberhard Karls Universität Tübingen. http:// tobias-lib.uni-tuebingen.de/volltexte/2007/3038/

Davis, S.J. 1980. Late Pleistocene and Holocene equid remains from Israel. Zoological Journal of the Linnean Society. 70:289-312.

Dive, J. and Eisenmann, V. 1991. Identification and discrimination of first phalanges from Pleistocene and modern Equus, wild and domestic, p. 278-315. In Meadow, R.H. and Uerpmann, H.-P. (eds.), Equids in the Ancient World, Volume II. Dr. Ludwig Reichert Verlag, Wiesbaden.

Dublyansky, V.N. and Lomaev, A.A. 1980. Karst caves of the Ukraine. Naukova Dumka Publishers, Kiev. (in Russian)

Eisenmann, V. 1979. Les métapodes d'Equus sensu lato (Mammalia, Perissodactyla). Géobios, 12:863-886.

Eisenmann, V. 1980. Les chevaux (Equus sensu lato) fossiles et actuels: crânes et dents jugales supérieures. CNRS, Paris.

Eisenmann, V. 1981. Étude des dents jugales inférieures des Equus (Mammalia, Perissodactyla) actuels et fossiles. Palaeovertebrata, 10:127-226.
Eisenmann, V. 1984. Sur quelques caractères adaptatifs du squelette d'Equus (Mammalia, Perissodactyla) et leurs implications paléoécologiques. Bulletin $d u$ muséum national d'histoire naturelle, Série 4(6), Section $C$, Sciences de la terre: paléontologie, géologie, minéralogie, 2:185-195.

Eisenmann, V. 1986. Comparative osteology of modern and fossil horses, half-asses, and asses, p. 67-116. In Meadow, R.H. and Uerpmann, H.-P. (eds.), Equids in the Ancient World, Volume I. Dr. Ludwig Reichert Verlag, Wiesbaden.

Eisenmann, V. 1991. Proportions squelettiques de chevaux quaternaires et actuels. Géobios, 13:25-32.

Eisenmann, V. 2004. Equus: an evolution without lineages? Terra nostra, 2004/2:101-104.

Eisenmann, V. 2006. Discriminating Equus skulls: the Franck's Index and the new Palatal Index, p. 172182. In Mashkour, M. (ed.), Equids in time and space, Proceedings of the $9^{\text {th }}$ Conference of the International Council of Archaeozoology, Durham, August 2002. Oxbow, Oxford.

Eisenmann, V. 2010. Sussemionus, a new subgenus of Equus (Perissodactyla, Mammalia). Comptes rendus biologies, 333:235-240.

Eisenmann, V. and Baryshnikov, G.F. 1994. Equus cf. taubachensis et E. hydruntinus de la grotte de Prolom 2 (Crimée, Ukraine). Bulletin du muséum national d'histoire naturelle 16:329-347.

Eisenmann, V. and Baylac, M. 2000. Extant and fossil Equus (Mammalia, Perissodactyla) skulls: a morphometric definition of the subgenus Equus. Zoologica Scripta, 29:89-100.

Eisenmann, V. and Bekouche, S. 1986. Identification and discrimination of metapodials from Pleistocene and modern Equus, wild and domestic, p. 117-163. In Meadow, R.H. and Uerpmann, H.-P. (eds.), Equids in the ancient world, Volume I. Dr. Ludwig Reichert Verlag, Wiesbaden.

Eisenmann, V. and Mashkour, M. 1999. The small equids of Binagady (Azerbaidjan) and Qazvin (Iran): E. hemionus binagadensis nov. subsp. and $E$. hydruntinus. Géobios, 32:105-122.

Eisenmann, V., Crégut-Bonnoure, E., and Moigne, A.-M. 1985. Equus mosbachensis et les grands chevaux de la Caune de l'Arago et de Lunel-Viel: crâniologie comparée. Bulletin du Muséum National d'Histoire Naturelle 4(7), Section C, No. 2:157-173.

Eisenmann, V., Alberdi, M.T., de Giuli, C., and Staesche, U. 1988. Methodology, p. 1-71. In Woodburne, M. and Sondaar, P. (eds.), Studying fossil horses, Collected papers after the 'New York International Hipparion Conference, 1981', Volume I. Brill, Leiden.

Forstén, A. 1986. A review of the Süssenborn horses and the origin of Equus hydruntinus Regalia. Quartärpaläontologie, 6:43-52.

Forstén, A. 1991. Size decrease in Pleistocene-Holocene true or caballoid horses of Europe. Mammalia, 55:407-419. 
Forstén, A. 1999. A review of Equus stenonis Cocchi (Perissodactyla, Equidae) and related forms. Quaternary Science Reviews, 18:1373-1408.

Forstén, A. and Ziegler, R. 1995. The horses (Mammalia, Equidae) from the early Wuermian of Villa Seckendorf, Stuttgart-Bad Cannstatt, Germany. Stuttgarter Beiträge zur Naturkunde, Series B, Geologie und Paläontologie 224. .

Gerasimenko, N. 2007. Environmental changes in the Crimean mountains during the Last Interglacial-middle pleniglacial as recorded by pollen and lithopedology. Quaternary International, 164-165:207-220.

Gaudzinski, S. 1995. Wallertheim revisited: a re-analysis of the fauna from the Middle Palaeolithic site of Wallertheim (Rheinhessen/Germany). Journal of Archaeological Science, 22:51-66.

Gray, J.E. 1821. On the natural arrangement of vertebrose animals. London medical repository, 15: 296310.

Gromova, V. 1949. Istorija loshadej (roda Equus) v Starom Svete, Chast' 2, Evoljutsija i klasifikatsija roda. Trudy paleontologicheskovo Instituta Akademii Nauk SSSR, 17:1-162. (in Russian)

Guthrie, R.D. 2001. Paleobehavior in Alaskan Pleistocene horses: social structure, maturation dates, uses of the landscape, and mortality patterns, p. 32-49. In Gerlach, S.C. and Murray, M.S. (eds.), People and Wildlife in Northern North America, Essays in Honor of R. Dale Guthrie, BAR International Series 944. Archaeopress, Oxford.

ICZN (International Commission on Zoological Nomenclature). 2003. Opinion 2027 (Case 3010), Usage of 17 specific names based on wild species which are pre-dated by or contemporary with those based on domestic animals (Lepidoptera, Osteichthyes, Mammalia): conserved. Bulletin of Zoological Nomenclature, 60:81-84.

Klingel, H. 1975. Social organisation and reproduction in equids. Journal of Reproduction and Fertility, Supplement 23:7-11.

Kuzmina, I.E. 1997. Horses of North Eurasia from the Pliocene till the present time. Russian Academy of Sciences, Proceedings of the Zoological Institute 273 (ed. N.K. Vereschagin), Saint-Petersburg. (in Russian with English summary)

Linklater, W.L., Cameron, E.Z., Stafford, K.J., and Veltman, C.J. 2000. Social and spatial structure and range use by Kaimanawa wild horses (Equus caballus: Equidae). New Zealand Journal of Ecology, 24:139-152.

Linnaeus, C. 1758. Systema naturae per regna tria naturae, secundum classes, ordines, genera, species, cum characteribus, differentiis, synonymis, locis, Tomus I. Editio decimal, refomata. Salvius, Stockholm.

Markova, A.K. 2011. Small mammals from Palaeolithic sites of the Crimea. Quaternary International, 231:22-27.
Markova, A.K., Puzachenko, A.Y., and van Kolfschoten T. 2010. The North Eurasian mammal assemblages during the end of MIS 3 (Brianskian-Late KarginianDenekamp Interstadial). Quaternary International, 212:149-158.

McDonnell, S.M. 2005. Sexual behaviour, p. 110-125. In Mills, D.S. and McDonnell, S.M. (eds.), The Domestic Horse, The Evolution, Development and Management of Its Behaviour. Cambridge University Press, Cambridge.

Nobis, G. 1971. Vom Wildpferd zum Hauspferd, Studien zur Phylogenie pleistozäner Equiden Eurasiens und das Domestikationsproblem unserer Hauspferde. Fundamenta Reihe B, Band 6. Böhlau Verlag, Köln.

Orlando, L., Mashkour, M., Burke, A., Douady, C.J., Eisenmann, V., and Hänni, C. 2006. Geographic distribution of an extinct equid (Equus hydruntinus: Mammalia, Equidae) revealed by morphological and genetical analysis of fossils. Molecular Ecology, 15:2083-2093.

Orlando, L., Metcalf, J.L., Alberdi, M.T., Telles-Antunes, M., Bonjean, D., Otte, M., Martin, F., Eisenmann, V., Mashkour, M., Morello, F., Prado, J.L., Salas-Gismondi, R., Shockey, B., Wrinn, P.J., Vasil'ev, S.K., Ovodov, N.D., Cherry, M.I., Hopwood, B., Male, D., Austin, J.J., Hänni, C., and Cooper, A. 2009. Revising the recent evolutionary history of equids using ancient DNA. Proceedings of the National Academy of Sciences, 106: 21754-21759

Patou-Mathis, M. and Chabai, V. 2003. Kabazi II (Crimée, Ukraine): un site d'abattage et de boucherie du Paléolithique moyen. l'Anthropologie, 107:223-253.

Regalia, E. 1907. Sull'Equus (Asinus) hydruntinus Regalia della grotta di Romanelli (Castro, Lecce). Archivio per l'antropologia e l'etnologia, 37:375-390.

Reynaud Savioz, N. and Morel, P. 2005. La faune de Nadaouiyeh Aïn Askar (Syrie centrale, Pléistocène moyen): aperçu et perspectives. Revue de Paléobiologie, 10:31-35 (Volume spéciale).

Rousseau, D.-D., Gerasimenko, N., Matviischina, Z., and Kukla, G. 2001. Late Pleistocene environments of the Central Ukraine. Quaternary Research, 56:349-356.

Russanov, B.S. 1968. Biostratigraphy of the Cenozoic sediments of southern Yakutia. Nauka, Moscow. [In Russian]

Schreve, D.C. 1997. Mammalian biostratigraphy of the later Middle Pleistocene in Britain. Unpublished PhD thesis, University College London.

Silver, I.A. 1969. The ageing of domestic animals, p. 283-302. In Brothwell, D. and Higgs, E. (eds.), Science in Archaeology, A Survey of Progress and Research. Thames and Hudson, London.

Simpson, G.G. 1941. Large Pleistocene felines of North America. American Museum Novitates, 1136:1-28.

Simpson, G.G., Roe, A., and Lewontin, R.C. 1960. Quantitative Zoology (revised edition). Harcourt Brace, New York.

Smit, A. 1996. Equus hydruntinus uit de groeve Maastricht-Belvédère. Cranium 13:53-57. 
Spassov, N. and Iliev, N. 1997. The wild horses of eastern Europe and the polyphyletic origin of the domestic horse, p. 753-760. In Kokabi, M. and Wahl, J. (eds.), Proceedings of the $7^{\text {th }}$ ICAZ conference (Konstanz, 26/09/1994-01/10/1994), Anthropozoologica 25-26. L'Homme et l'Animal, Société de Recherche Interdisciplinaire, Paris.

Stankovic, A., Doan, K., Mackiewicz, P., Ridush, B., Baca, M., Gromadka, R., Socha, P., Weglenski, P., Nadachowski, A., and Stefaniak, K., 2011. First ancient DNA sequences of the Late Pleistocene red deer (Cervus elaphus) from the Crimea, Ukraine. Quaternary International, 245:262-267.

Stehlin, H.-G. and Graziosi, P. 1935. Ricerche sugli Asinidi fossili d'Europa. Mémoires de la Société Paléontologique Suisse, 56:1-73.

Stewart, J.R. 2007. Neanderthal extinction as part of the faunal change in Europe during Oxygen Isotope Stage 3. Acta Zoologica Cracoviensia, 50A:93-124.

van Asperen, E.N. 2009. An outline of late Middle Pleistocene horse biostratigraphy, A contribution to the chronology and ecology of the European Early and Middle Palaeolithic. Unpublished PhD thesis, University of York, York, UK.

van Asperen, E.N. 2010. Ecomorphological adaptations to climate and substrate in late Middle Pleistocene caballoid horses. Palaeogeography, Palaeoclimatology, Palaeoecology, 297:584-596. van Asperen, E.N. In press. Implications of age variation and sexual dimorphism in modern equids for Middle Pleistocene equid taxonomy. International Journal of Osteoarchaeology.

Vangenheim, E.A. 1966. Description of the remains of E. caballus cf. taubachensis from Upper Palaeolithic site Sungir, p. 118-139. In: Sukachev, V.N., Gromov, V.I. and Bader, O.N. (eds.), Upper Palaeolithic site Sungir. Trudy Geologicheskogo Instituta Akademii Nauk SSSR 162. [in Russian]

Von den Driesch, A. 1976. A guide to the measurement of animal bones from archaeological sites. Peabody Museum Bulletin 1, Cambridge.

Vremir, M. and Ridush, B. 2005. The Emine-Bair-Khosar "mega trap" (Ukraine). Mitteilungen der Kommission für Quartärforschung der österreichischen Akademie der Wissenschaften 14:235-239.

Weinstock, J., Willerslev, E., Sher, A., Tong, W., Ho, S.Y.W., Rubenstein, D., Storer, J., Burns, J., Martin, L., Bravi, C., Prieto, A., Froese, D., Scott, E., Xulong, L., Cooper, A. 2005. Evolution, systematics, and phylogeography of Pleistocene horses in the New World: a molecular perspective. PLoS Biology, 3:e241.

Wilms, C. 1989. Zum Aussterben des europäischen Wildesels. Germania, 67:143-148. 


\section{APPENDIXES}

APPENDIX 1. Full dataset for the equid remains from Emine-Bair-Khosar, recovered during field seasons 1999-2009. PE note: this appendix is only available online.

\section{APPENDIX 2}

APPENDIX 2. Measurements on the EBK cranial specimens and mean values for comparative material; Equus hemionus and Equus przewalskii: Eisenmann, 1980; Equus ferus gallicus: Cardoso and Eisenmann, 1989; Equus ferus latipes: Kuzmina, 1997; Equus hydruntinus: Burke et al., 2003.

\begin{tabular}{|l|c|c|c|c|c|c|c|}
\hline Specimen / Species & nmax & V16 & V23 & V3 & V4 & V2-5 & V5 \\
\hline EBK Bc M1 (141) & - & 54.4 & - & 97.3 & 103.4 & - & - \\
EBK Ba2 C1(B) 384 & - & 52.9 & 320.0 & 101.5 & 106.8 & 119.3 & 88.0 \\
EBK Bm001 & - & - & - & - & - & 126.2 & 118.6 \\
\hline Equus hemionus & 45 & 56.4 & 341.0 & 111.3 & 106.0 & 109.4 & 105.2 \\
Equus hydruntinus (Kabazi II) & 2 & - & - & - & - & - & - \\
Equus hydruntinus (Lunel-Viel) & 1 & - & - & 85.5 & - & 99.0 & 87.0 \\
\hline Equus przewalskii & 20 & 65.3 & 373.6 & 101.5 & 118.4 & 131.6 & 127.8 \\
Equus ferus gallicus & 4 & 64.0 & 384.5 & 100.0 & - & 140.3 & 122.0 \\
Equus ferus latipes & 6 & - & - & - & - & - & -- \\
\hline Specimen / Species & $\mathbf{n m a x}$ & $\mathbf{V 1 7}$ & $\mathbf{V 1 7 b}$ & $\mathbf{V 1 3}$ & $\mathbf{V 2 5}$ & $\mathbf{V 2 8}$ & $\mathbf{V 2 0}$ \\
\hline EBK Bc M1 (141) & - & - & - & 189.0 & 97.8 & 93.0 & - \\
EBK Ba2 C1(B) 384 & - & 57.4 & 40.3 & 184.0 & 88.8 & 90.0 & - \\
EBK Bm001 & - & 67.5 & 48.2 & 175.5 & - & - & - \\
\hline Equus hemionus & 45 & 54.5 & 39.8 & 195.5 & 98.2 & 87.1 & 14.1 \\
Equus hydruntinus (Kabazi II) & 2 & 59.8 & 39.6 & - & - & - & - \\
Equus hydruntinus (Lunel-Viel) & 1 & - & 36.5 & - & - & 84.0 & - \\
\hline Equus przewalskii & 20 & 63.4 & 42.3 & 210.4 & 100.8 & 97.7 & 12.9 \\
Equus ferus gallicus & 4 & 74.0 & 48.5 & 208.0 & 108.0 & 97.3 & 13.7 \\
Equus ferus latipes & 6 & - & - & 220.6 & - & 113.5 & - \\
\hline
\end{tabular}




\section{APPENDIX 3}

APPENDIX 3. Mean, minimum, and maximum values for the upper dental elements of the EBK equid specimens and comparative material; $\mathrm{L}=$ length, $\mathrm{W}=$ width, Lprot=length of the protocone; Equus hemionus: Eisenmann, 1980; Equus hydruntinus (Lunel-Viel): Bonifay, 1991; Equus hydruntinus (Crimea), Equus przewalskii, Equus ferus latipes: Kuzmina, 1997; Equus ferus gallicus: Eisenmann, online data.

\begin{tabular}{|c|c|c|c|c|c|c|c|c|c|c|}
\hline P2 & nmax & Lmean & $\min$ & $\max$ & Wmean & $\min$ & $\max$ & & & \\
\hline EBK small & 8 & 32.5 & 31.8 & 33.7 & 21.8 & 20.1 & 24.5 & & & \\
\hline EBK large & 3 & 37.6 & 35.4 & 41.0 & 24.0 & 22.9 & 24.9 & & & \\
\hline $\begin{array}{l}\text { Equus hemionus } \\
\text { Equus hydruntinus }\end{array}$ & 23 & 34.3 & 28.5 & 39.0 & 24.2 & 22.3 & 26.0 & & & \\
\hline $\begin{array}{l}\text { (Lunel-Viel) } \\
\text { Equus hydruntinus }\end{array}$ & 4 & 31.5 & 31.0 & 31.8 & 22.3 & 21.0 & 23.5 & & & \\
\hline (Crimea) & 11 & 31.4 & 29.3 & 32.5 & 21.3 & 19.8 & 22.5 & & & \\
\hline $\begin{array}{l}\text { Equus przewalskii } \\
\text { Equus ferus }\end{array}$ & 21 & 40.0 & 36.2 & 46.5 & 26.7 & 24.0 & 31.1 & & & \\
\hline gallicus & 10 & 37.4 & 36.0 & 39.0 & 25.0 & 24.0 & 26.0 & & & \\
\hline Equus ferus latipes & 16 & 38.8 & 35.2 & 41.5 & 26.1 & 22.3 & 28.6 & & & \\
\hline P3/4 & nmax & Lmean & $\min$ & $\max$ & Wmean & $\min$ & $\max$ & Lprot & $\min$ & $\max$ \\
\hline EBK small & 17 & 25.2 & 23.5 & 27.4 & 24.2 & 21.9 & 25.6 & 8.4 & 7.0 & 10.2 \\
\hline EBK large & 7 & 29.2 & 28.2 & 33.1 & 25.0 & 23.7 & 28.8 & 12.6 & 9.5 & 15.0 \\
\hline $\begin{array}{l}\text { Equus hemionus } \\
\text { Equus hydruntinus }\end{array}$ & 47 & 25.2 & 22.5 & 28.5 & 25.9 & 24.0 & 28.5 & 11.4 & 8.0 & 16.0 \\
\hline $\begin{array}{l}\text { (Lunel-Viel) } \\
\text { Equus hydruntinus }\end{array}$ & 21 & 23.9 & 20.7 & 27.0 & 23.6 & 21.8 & 24.9 & 8.0 & 6.2 & 9.4 \\
\hline (Crimea) & 38 & 25.0 & 21.6 & 27.3 & 23.1 & 21.2 & 25.0 & 9.2 & 7.5 & 11.2 \\
\hline $\begin{array}{l}\text { Equus przewalskii } \\
\text { Equus ferus }\end{array}$ & 44 & 29.0 & 21.2 & 34.2 & 28.8 & 23.0 & 32.5 & 13.8 & 11.0 & 16.3 \\
\hline gallicus & 26 & 28.3 & 26.0 & 30.0 & 28.0 & 26.0 & 30.0 & 12.8 & 10.0 & 15.0 \\
\hline Equus ferus latipes & 22 & 30.8 & 28.0 & 34.0 & 30.0 & 27.7 & 31.0 & 13.8 & 10.6 & 16.6 \\
\hline M1/2 & nmax & Lmean & $\min$ & $\max$ & Wmean & $\min$ & $\max$ & Lprot & $\min$ & $\max$ \\
\hline EBK small & 17 & 22.3 & 20.9 & 24.0 & 23.3 & 21.7 & 24.9 & 8.6 & 7.4 & 9.9 \\
\hline EBK large & 4 & 26.0 & 24.4 & 30.3 & 23.4 & 22.5 & 24.2 & 12.7 & 11.5 & 15.4 \\
\hline $\begin{array}{l}\text { Equus hemionus } \\
\text { Equus hydruntinus }\end{array}$ & 48 & 22.4 & 19.0 & 26.0 & 23.6 & 20.3 & 26.0 & 11.0 & 8.5 & 15.5 \\
\hline $\begin{array}{l}\text { (Lunel-Viel) } \\
\text { Equus hydruntinus }\end{array}$ & 24 & 23.0 & 19.8 & 27.6 & 22.7 & 19.8 & 24.9 & 8.7 & 7.1 & 10.5 \\
\hline (Crimea) & 55 & 22.0 & 19.5 & 27.5 & 22.0 & 20.0 & 25.0 & 8.6 & 6.0 & 11.5 \\
\hline $\begin{array}{l}\text { Equus przewalskii } \\
\text { Equus ferus }\end{array}$ & 44 & 25.9 & 20.4 & 31.0 & 27.4 & 23.0 & 31.0 & 13.9 & 11.8 & 16.9 \\
\hline gallicus & 26 & 25.1 & 23.0 & 26.0 & 26.3 & 24.5 & 28.5 & 13.8 & 11.0 & 16.0 \\
\hline Equus ferus latipes & 28 & 27.7 & 25.1 & 34.5 & 28.7 & 25.2 & 33.5 & 14.9 & 13.2 & 17.0 \\
\hline M3 & nmax & Lmean & $\min$ & $\max$ & Wmean & $\min$ & $\max$ & & & \\
\hline EBK small & 10 & 24.3 & 20.1 & 27.3 & 20.9 & 19.6 & 23.1 & & & \\
\hline EBK large & 2 & 25.8 & 22.0 & 29.5 & 21.6 & 18.8 & 24.3 & & & \\
\hline $\begin{array}{l}\text { Equus hemionus } \\
\text { Equus hydruntinus }\end{array}$ & 22 & 24.4 & 22.0 & 27.0 & 19.8 & 17.0 & 22.5 & & & \\
\hline $\begin{array}{l}\text { (Lunel-Viel) } \\
\text { Equus hydruntinus }\end{array}$ & 10 & 21.7 & 19.2 & 24.3 & 19.2 & 16.7 & 20.6 & & & \\
\hline (Crimea) & 30 & 22.6 & 19.5 & 25.5 & 19.2 & 16.0 & 21.2 & & & \\
\hline $\begin{array}{l}\text { Equus przewalskii } \\
\text { Equus ferus }\end{array}$ & 22 & 28.5 & 24.0 & 32.8 & 24.2 & 20.0 & 27.0 & & & \\
\hline gallicus & 11 & 26.8 & 25.0 & 29.0 & 22.8 & 22.0 & 24.0 & & & \\
\hline Equus ferus latipes & 11 & 29.1 & 25.9 & 31.2 & 25.6 & 22.8 & 27.7 & & & \\
\hline
\end{tabular}




\section{APPENDIX 4}

APPENDIX 4. Mean, minimum, and maximum values for the lower dental elements of the EBK equid specimens and comparative material; L=length, W=width; Equus hemionus: Eisenmann, 1981; Equus hydruntinus (Lunel-Viel): Bonifay, 1991; Equus hydruntinus (Crimea), Equus przewalskii, Equus ferus latipes: Kuzmina, 1997; Equus ferus gallicus: Eisenmann, online data

\begin{tabular}{|c|c|c|c|c|c|c|c|c|c|c|}
\hline p2 & nmax & Lmean & $\min$ & $\max$ & Wmean & $\min$ & $\max$ & LFmean & $\min$ & $\max$ \\
\hline EBK small & 5 & 27.4 & 24.5 & 28.7 & 14.2 & 13.2 & 15.6 & 12.4 & 11.6 & 13.7 \\
\hline EBK large & 2 & 40.0 & - & - & 16.7 & 16.3 & 17.0 & 17.7 & 15.7 & 19.6 \\
\hline $\begin{array}{l}\text { Equus hemionus } \\
\text { Equus hydruntinus }\end{array}$ & 24 & 29.1 & 26.0 & 33.5 & 14.1 & 12.0 & 17.0 & 13.9 & 10.0 & 17.0 \\
\hline $\begin{array}{l}\text { (Lunel-Viel) } \\
\text { Equus hydruntinus }\end{array}$ & 8 & 26.9 & 25.5 & 28.4 & 14.4 & 13.2 & 15.2 & - & - & - \\
\hline (Crimea) & 25 & 27.2 & 25.0 & 30.0 & 15.3 & 13.5 & 18.0 & 12.8 & 10.5 & 15.5 \\
\hline Equus przewalskii & 19 & 33.3 & 29.3 & 38.0 & 18.1 & 15.0 & 19.3 & 16.8 & 15.5 & 18.5 \\
\hline Equus ferus gallicus & 11 & 31.4 & 29.0 & 36.0 & 15.3 & 14.0 & 17.0 & 16.0 & 13.0 & 17.0 \\
\hline Equus ferus latipes & 28 & 34.5 & 32.0 & 40.0 & 17.2 & 15.0 & 21.0 & 17.5 & 16.0 & 20.0 \\
\hline $\mathrm{p} 3 / 4$ & nmax & Lmean & $\min$ & $\max$ & Wmean & $\min$ & $\max$ & LFmean & $\min$ & $\max$ \\
\hline EBK small & 12 & 24.5 & 21.1 & 26.1 & 14.9 & 13.2 & 17.2 & 12.4 & 10.7 & 15.5 \\
\hline EBK large & 4 & 33.1 & 32.5 & 33.8 & 17.4 & 16.8 & 17.6 & 17.1 & 16.0 & 18.3 \\
\hline $\begin{array}{l}\text { Equus hemionus } \\
\text { Equus hydruntinus }\end{array}$ & 47 & 25.5 & 22.0 & 31.0 & 15.7 & 13.5 & 19.0 & 12.2 & 9.0 & 15.5 \\
\hline $\begin{array}{l}\text { (Lunel-Viel) } \\
\text { Equus hydruntinus }\end{array}$ & 19 & 24.9 & 23.3 & 26.0 & 16.3 & 13.0 & 18.3 & - & - & - \\
\hline (Crimea) & 55 & 23.7 & 21.6 & 25.6 & 16.5 & 14.2 & 18.2 & 11.6 & 8.2 & 14.0 \\
\hline Equus przewalskii & 38 & 28.4 & 24.1 & 31.6 & 20.3 & 17.6 & 22.8 & 14.8 & 12.5 & 18.2 \\
\hline Equus ferus gallicus & 26 & 28.9 & 26.5 & 34.0 & 17.1 & 15.0 & 19.0 & 13.3 & 10.0 & 16.0 \\
\hline Equus ferus latipes & 64 & 29.3 & 26.2 & 33.3 & 19.4 & 16.6 & 22.0 & 14.3 & 10.4 & 17.4 \\
\hline $\mathrm{m} 1 / 2$ & nmax & Lmean & $\min$ & $\max$ & Wmean & $\min$ & $\max$ & LFmean & $\min$ & $\max$ \\
\hline EBK small & 11 & 22.6 & 20.9 & 24.0 & 13.6 & 12.2 & 16.0 & 9.4 & 6.4 & 12.1 \\
\hline EBK large & 4 & 30.7 & 29.9 & 31.8 & 15.3 & 14.8 & 15.6 & 13.2 & 11.4 & 14.6 \\
\hline $\begin{array}{l}\text { Equus hemionus } \\
\text { Equus hydruntinus }\end{array}$ & 48 & 23.1 & 19.5 & 30.0 & 14.2 & 11.5 & 17.0 & 9.3 & 6.0 & 12.0 \\
\hline $\begin{array}{l}\text { (Lunel-Viel) } \\
\text { Equus hydruntinus }\end{array}$ & 21 & 22.3 & 20.5 & 25.8 & 14.5 & 11.0 & 18.2 & - & - & - \\
\hline (Crimea) & 64 & 22.2 & 18.6 & 29.5 & 14.7 & 12.5 & 16.8 & 7.5 & 5.0 & 11.0 \\
\hline Equus przewalskii & 34 & 26.8 & 22.0 & 30.9 & 18.4 & 15.6 & 21.0 & 10.5 & 7.4 & 13.6 \\
\hline Equus ferus gallicus & 26 & 26.6 & 23.5 & 29.0 & 15.7 & 14.0 & 17.3 & 10.4 & 8.0 & 15.0 \\
\hline Equus ferus latipes & 79 & 27.2 & 23.5 & 33.2 & 18.0 & 15.2 & 20.6 & 11.0 & 7.2 & 14.5 \\
\hline $\mathrm{m} 3$ & $\mathrm{nmax}$ & Lmean & $\min$ & $\max$ & Wmean & $\min$ & $\max$ & LFmean & $\min$ & $\max$ \\
\hline EBK small & 9 & 25.9 & 20.9 & 28.6 & 12.5 & 10.8 & 13.5 & 10.6 & 8.3 & 11.7 \\
\hline EBK large & 2 & 30.3 & 30.2 & 30.3 & 13.4 & 13.1 & 13.6 & 12.0 & - & - \\
\hline $\begin{array}{l}\text { Equus hemionus } \\
\text { Equus hydruntinus }\end{array}$ & 22 & 28.7 & 25.0 & 35.0 & 12.7 & 11.0 & 15.5 & - & - & - \\
\hline $\begin{array}{l}\text { (Lunel-Viel) } \\
\text { Equus hydruntinus }\end{array}$ & 9 & 26.4 & 24.3 & 27.5 & 12.2 & 10.2 & 13.6 & - & - & - \\
\hline (Crimea) & 20 & 25.4 & 22.0 & 27.5 & 11.6 & 12.0 & 14.0 & 6.8 & 5.3 & 8.0 \\
\hline Equus przewalskii & 18 & 33.6 & 30.0 & 37.5 & 15.7 & 13.8 & 17.8 & 11.5 & 8.5 & 13.6 \\
\hline Equus ferus gallicus & 13 & 32.0 & 29.0 & 34.5 & 13.9 & 12.0 & 15.0 & - & - & - \\
\hline Equus ferus latipes & 35 & 34.0 & 30.0 & 39.6 & 15.6 & 13.0 & 17.5 & 11.4 & 7.3 & 14.1 \\
\hline
\end{tabular}




\section{APPENDIX 5}

APPENDIX 5. Longbone mean, minimum, and maximum values for the EBK specimens and comparative material; Equus hemionus, Equus ferus gallicus and Equus przewalskii: Eisenmann, online data; Equus hydruntinus: Kuzmina, 1997; Equus ferus latipes: Kuzmina, 1997, Eisenmann, 1991.

\begin{tabular}{|c|c|c|c|c|c|c|c|c|c|c|}
\hline Humerus & nmax & mean & $\begin{array}{l}\text { GL } \\
\min \end{array}$ & $\max$ & mean & $\begin{array}{l}\text { Bp } \\
\text { min }\end{array}$ & $\max$ & & & \\
\hline EBK small $\mathrm{Ba} / \mathrm{Bc}$ & 4 & 248.8 & 246.2 & 251.7 & 79.9 & 75.8 & 84.0 & & & \\
\hline EBK large $\mathrm{Ba} / \mathrm{Bc}$ & 2 & 322.7 & 317.8 & 327.5 & 95.6 & 94.3 & 96.9 & & & \\
\hline $\begin{array}{l}\text { Equus hemionus } \\
\text { Equus ferus }\end{array}$ & 10 & 252.2 & 235.0 & 259.0 & 81.1 & 75.0 & 88.0 & & & \\
\hline gallicus & 17 & 278.3 & 267.5 & 295.0 & 94.5 & 90.0 & 105.0 & & & \\
\hline Equus przewalskii & 42 & 263.4 & 247.0 & 287.0 & 85.7 & 70.0 & 92.0 & & & \\
\hline Equus ferus latipes & 9 & 285.3 & 273.0 & 300.0 & 97.6 & 95.7 & 102.0 & & & \\
\hline Radius & nmax & \multicolumn{3}{|c|}{ GL } & \multicolumn{3}{|c|}{$\mathrm{Bp}$} & mean & $\begin{array}{l}\text { SD } \\
\min \end{array}$ & $\max$ \\
\hline $\begin{array}{l}\text { EBK small } \mathrm{Ba} / \mathrm{Bc} \\
\text { EBK large } \mathrm{Bb}\end{array}$ & $\begin{array}{c}10 \\
1 \\
\end{array}$ & $\begin{array}{l}301.2 \\
369.0 \\
\end{array}$ & $\begin{array}{c}284.0 \\
-\end{array}$ & $\begin{array}{c}322.0 \\
-\end{array}$ & $\begin{array}{l}71.0 \\
92.0 \\
\end{array}$ & $\begin{array}{c}65.0 \\
- \\
\end{array}$ & $\begin{array}{c}82.7 \\
- \\
\end{array}$ & $\begin{array}{l}35.8 \\
45.2 \\
\end{array}$ & $\begin{array}{c}33.9 \\
-\end{array}$ & $\begin{array}{c}41.1 \\
-\end{array}$ \\
\hline $\begin{array}{l}\text { Equus hemionus } \\
\text { Equus hydruntinus } \\
\text { (Crimea) }\end{array}$ & $\begin{array}{l}10 \\
39 \\
\end{array}$ & $\begin{array}{l}303.4 \\
291.3 \\
\end{array}$ & $\begin{array}{r}289.0 \\
289.0 \\
\end{array}$ & $\begin{array}{l}316.0 \\
293.0 \\
\end{array}$ & $\begin{array}{l}71.6 \\
66.9 \\
\end{array}$ & $\begin{array}{l}67.0 \\
60.5 \\
\end{array}$ & $\begin{array}{l}76.0 \\
70.0 \\
\end{array}$ & $\begin{array}{r}33.5 \\
33.6 \\
\end{array}$ & $\begin{array}{r}32.0 \\
30.3 \\
\end{array}$ & $\begin{array}{r}35.3 \\
36.0 \\
\end{array}$ \\
\hline $\begin{array}{l}\text { Equus ferus } \\
\text { gallicus } \\
\text { Equus przewalskii } \\
\text { Equus ferus latipes }\end{array}$ & $\begin{array}{c}23 \\
42 \\
107 \\
\end{array}$ & $\begin{array}{l}326.8 \\
312.1 \\
352.6 \\
\end{array}$ & $\begin{array}{l}312.0 \\
296.0 \\
327.0 \\
\end{array}$ & $\begin{array}{l}354.0 \\
330.0 \\
367.0\end{array}$ & $\begin{array}{l}87.1 \\
76.7 \\
91.6 \\
\end{array}$ & $\begin{array}{l}84.0 \\
72.0 \\
80.0 \\
\end{array}$ & $\begin{array}{l}94.0 \\
83.0 \\
99.0 \\
\end{array}$ & $\begin{array}{c}41.7 \\
36.0 \\
- \\
\end{array}$ & $\begin{array}{c}37.5 \\
31.5 \\
-\end{array}$ & $\begin{array}{r}48.0 \\
40.0 \\
- \\
\end{array}$ \\
\hline Femur & nmax & \multicolumn{3}{|c|}{ GL } & \multicolumn{3}{|c|}{ SD } & & & \\
\hline $\begin{array}{l}\text { EBK small } \mathrm{Ba} / \mathrm{Bc} \\
\text { EBK large }\end{array}$ & $\begin{array}{l}4 \\
-\end{array}$ & $\begin{array}{c}333.3 \\
-\end{array}$ & $\begin{array}{c}322.3 \\
-\end{array}$ & $\begin{array}{c}342.2 \\
-\end{array}$ & $\begin{array}{c}33.0 \\
-\end{array}$ & $\begin{array}{c}31.1 \\
-\end{array}$ & $\begin{array}{c}34.8 \\
-\end{array}$ & & & \\
\hline $\begin{array}{l}\text { Equus hemionus } \\
\text { Equus hydruntinus } \\
\text { (Crimea) }\end{array}$ & $\begin{array}{l}10 \\
-\end{array}$ & $\begin{array}{c}337.3 \\
-\end{array}$ & $\begin{array}{c}319.0 \\
-\end{array}$ & $\begin{array}{c}356.0 \\
-\end{array}$ & $\begin{array}{c}32.2 \\
-\end{array}$ & $\begin{array}{c}29.0 \\
-\end{array}$ & $\begin{array}{c}34.0 \\
-\end{array}$ & & & \\
\hline $\begin{array}{l}\text { Equus ferus } \\
\text { gallicus } \\
\text { Equus przewalskii } \\
\text { Equus ferus latipes }\end{array}$ & $\begin{array}{c}3 \\
43 \\
8 \\
\end{array}$ & $\begin{array}{l}382.7 \\
357.6 \\
378.6 \\
\end{array}$ & $\begin{array}{l}375.0 \\
333.0 \\
366.0 \\
\end{array}$ & $\begin{array}{l}394.0 \\
392.0 \\
395.5 \\
\end{array}$ & $\begin{array}{c}41.0 \\
37.4 \\
- \\
\end{array}$ & $\begin{array}{c}- \\
33.0 \\
- \\
\end{array}$ & $\begin{array}{c}- \\
44.0 \\
- \\
\end{array}$ & & & \\
\hline Tibia & nmax & \multicolumn{3}{|c|}{$\mathbf{G L}$} & \multicolumn{3}{|c|}{$\mathrm{Bp}$} & \multicolumn{3}{|c|}{ SD } \\
\hline EBK small (all) & 12 & 324.5 & 310.5 & 342.5 & 79.9 & 74.7 & 92.5 & 37.1 & 35.0 & 40.4 \\
\hline EBK small $\mathrm{Ba} / \mathrm{Bc}$ & 11 & 324.9 & 310.5 & 342.5 & 80.6 & 75.4 & 92.5 & 37.1 & 35.0 & 40.4 \\
\hline EBK small Bb & 1 & 320.0 & - & - & 74.7 & - & - & 36.5 & - & - \\
\hline EBK large $\mathrm{Bb}$ & 1 & 367.7 & - & - & 120.5 & - & - & 50.4 & - & - \\
\hline $\begin{array}{l}\text { Equus hemionus } \\
\text { Equus hydruntinus } \\
\text { (Crimea) }\end{array}$ & $\begin{array}{l}10 \\
62\end{array}$ & 324.8 & 310.0 & 335.0 & 83.6 & $\begin{array}{r}78.1 \\
74.6\end{array}$ & $\begin{array}{l}87.0 \\
79.0\end{array}$ & 35.9 & 31.0 & 38.5 \\
\hline $\begin{array}{l}\text { Equus ferus } \\
\text { gallicus }\end{array}$ & 22 & 343.6 & 327.0 & 363.5 & 102.8 & 100.0 & 106.0 & 45.5 & 42.0 & 49.0 \\
\hline Equus przewalskii & 44 & 326.1 & 309.0 & 350.0 & 89.9 & 82.0 & 99.0 & 40.2 & 33.0 & 46.0 \\
\hline Equus ferus latipes & 34 & 368.2 & 352.7 & 381.0 & 104.6 & 98.0 & 114.0 & - & - & - \\
\hline
\end{tabular}




\section{APPENDIX 6}

APPENDIX 6. Mean values for metacarpal measurements of the EBK specimens and comparative material; Equus hemionus, Equus africanus and Equus przewalskii: Eisenmann, 1979; Equus hydruntinus (Crimea) and Equus ferus latipes: Kuzmina, 1997; Equus hydruntinus (Italy): Eisenmann \& Bekouche, 1986; Equus hydruntinus (Lunel-Viel): Bonifay, 1991; Equus ferus gallicus: Eisenmann, online data.

\begin{tabular}{|l|c|c|c|c|c|c|c|}
\hline Specimen / Species & nmax & V1 & V3 & V4 & V5 & V6 & V10 \\
\hline EBK small (all) & 5 & 221.9 & 28.8 & 23.5 & 43.2 & 29.4 & 40.1 \\
EBK small Ba/Bc & 4 & 220.4 & 28.8 & 23.5 & 43.2 & 29.5 & - \\
EBK small Bb & 1 & 228.0 & 28.9 & 23.7 & 43.4 & 29.3 & 40.1 \\
EBK large (all) & 5 & 243.0 & 36.5 & 27.1 & 54.9 & 35.9 & 54.9 \\
EBK large Ba/Bc & 4 & 243.0 & 36.5 & 27.1 & 54.9 & 35.9 & - \\
EBK large Bb & 1 & - & - & - & - & - & 54.9 \\
\hline Equus hemionus & 22 & 214.1 & 25.7 & 21.1 & 43.2 & 27.0 & 38.9 \\
Equus africanus & 8 & 206.6 & 27.8 & 22.9 & 46.6 & 28.6 & 40.9 \\
Equus hydruntinus (Crimea) & 50 & 211.8 & 26.1 & 21.7 & 41.0 & 29.3 & - \\
Equus hydruntinus (Italy) & 30 & 212.8 & 28.0 & 23.2 & 42.0 & 28.2 & 38.9 \\
Equus hydruntinus (Lunel-Viel) & 12 & 190.2 & 24.6 & 21.0 & 36.2 & 25.1 & 32.4 \\
\hline Equus przewalskii & 17 & 214.7 & 31.5 & 23.9 & 48.5 & 29.9 & 44.7 \\
Equus ferus latipes & 79 & 235.2 & 39.1 & - & 56.4 & - & - \\
Equus ferus gallicus & 25 & 222.5 & 36.9 & 27.4 & 52.3 & 33.1 & 50.3 \\
Specimen / Species & $\mathbf{n m a x}$ & $\mathbf{V 1 1}$ & $\mathbf{V 1 2}$ & $\mathbf{V 1 3}$ & $\mathbf{V 1 4}$ & $\mathbf{V 7}$ & $\mathbf{V} 8$ \\
\hline EBK small (all) & 5 & 40.0 & 29.2 & 24.2 & 26.9 & 36.7 & 12.0 \\
EBK small Ba/Bc & 4 & 39.8 & 29.1 & - & - & - & - \\
EBK small Bb & 1 & 40.7 & 29.7 & 24.2 & 26.9 & 36.7 & 12.0 \\
EBK large & 5 & 54.5 & 40.2 & 33.8 & 36.0 & - & - \\
EBK large Ba/Bc & 4 & 53.3 & 39.4 & - & - & - & - \\
EBK large Bb & 1 & 59.2 & 43.4 & 33.8 & 36.0 & - & - \\
\hline Equus hemionus & 22 & 38.7 & 29.3 & 24.3 & 26.1 & 34.0 & 12.8 \\
Equus africanus & 8 & 40.6 & 30.1 & 24.8 & 27.0 & 38.2 & 13.0 \\
Equus hydruntinus (Crimea) & 50 & 36.9 & 28.2 & - & - & - & - \\
Equus hydruntinus (Italy) & 30 & 37.9 & 29.1 & 24.0 & 26.4 & 33.4 & 12.7 \\
Equus hydruntinus (Lunel-Viel) & 12 & 33.1 & 25.4 & - & - & - & - \\
\hline Equus przewalskii & 17 & 45.7 & 34.4 & 27.1 & 28.7 & 39.0 & 14.2 \\
Equus ferus latipes & 79 & 55.2 & - & - & - & - & - \\
Equus ferus gallicus & 25 & 51.7 & 37.9 & 29.3 & 31.1 & 41.5 & 16.9 \\
\hline
\end{tabular}




\section{APPENDIX 7}

APPENDIX 7. Mean values for metatarsal measurements of the EBK specimens and comparative material; measurements according to Eisenmann, 1979; Equus hemionus, Equus africanus and Equus przewalskii: Eisenmann, 1979; Equus hydruntinus (Crimea) and Equus ferus latipes: Kuzmina, 1997; Equus hydruntinus (Italy): Eisenmann \& Bekouche, 1986; Equus hydruntinus (Lunel-Viel): Bonifay, 1991; Equus ferus gallicus: Eisenmann, online data.

\begin{tabular}{|l|c|c|c|c|c|c|c|}
\hline Specimen / Species & nmax & V1 & V3 & V4 & V5 & V6 & V10 \\
\hline EBK small (all) & 8 & 253.5 & 27.1 & 27.2 & 41.9 & 37.1 & 39.2 \\
EBK small Ba/Bc & 7 & 253.0 & 26.8 & 27.2 & 41.9 & 37.1 & 39.7 \\
EBK small Bb & 1 & 256.2 & 28.8 & 27.0 & 42.5 & 37.0 & 38.2 \\
EBK large Ba/Bc & 2 & 284.3 & 37.5 & 34.6 & 57.9 & 51.0 & - \\
\hline Equus hemionus & 22 & 250.6 & 25.2 & 25.3 & 40.5 & 35.1 & 38.0 \\
Equus africanus & 8 & 242.9 & 26.5 & 26.5 & 44.7 & 36.1 & 40.9 \\
Equus hydruntinus (Crimea) & 37 & 251.2 & 25.5 & 25.7 & 40.5 & 36.1 & - \\
Equus hydruntinus (Italy) & 17 & 235.6 & 25.8 & 26.4 & 40.1 & 32.6 & 38.1 \\
Equus hydruntinus (Lunel-Viel) & 17 & 229.3 & 24.9 & 24.2 & 36.5 & 30.8 & 33.0 \\
\hline Equus przewalskii & 18 & 254.7 & 29.8 & 28.0 & 48.9 & 39.8 & 46.2 \\
Equus ferus latipes & 60 & 281.2 & 36.2 & - & 56.5 & - & - \\
Equus ferus gallicus & 17 & 267.6 & 36.1 & 34.3 & 54.2 & 42.2 & 52.3 \\
\hline Specimen / Species & $\mathbf{n m a x}$ & $\mathbf{V 1 1}$ & $\mathbf{V 1 2}$ & $\mathbf{V 1 3}$ & $\mathbf{V 1 4}$ & $\mathbf{V 7}$ & V8 \\
\hline EBK small (all) & 8 & 38.1 & 29.9 & 23.8 & 26.1 & 37.6 & 9.6 \\
EBK small Ba/Bc & 7 & 38.3 & 30.3 & 24.3 & 26.3 & 37.3 & 9.7 \\
EBK small Bb & 1 & 37.3 & 27.5 & 22.7 & 25.8 & 38.1 & 9.5 \\
EBK large Ba/Bc & 2 & 55.7 & 43.0 & - & - & - & - \\
\hline Equus hemionus & 22 & 37.5 & 30.0 & 23.9 & 26.5 & 35.9 & 9.0 \\
Equus africanus & 8 & 40.6 & 31.3 & 24.9 & 27.4 & 39.4 & 10.8 \\
Equus hydruntinus (Crimea) & 37 & 37.6 & 29.0 & - & - & - & - \\
Equus hydruntinus (Italy) & 17 & 36.7 & 29.9 & 24.6 & 26.8 & 36.0 & 8.9 \\
Equus hydruntinus (Lunel-Viel) & 17 & 32.6 & 25.8 & - & - & - & - \\
\hline Equus przewalskii & 18 & 45.3 & 34.8 & 26.2 & 28.8 & 42.5 & 12.4 \\
Equus ferus latipes & 60 & 56.0 & - & - & - & - & - \\
Equus ferus gallicus & 17 & 53.6 & 39.9 & 29.6 & 33.2 & 47.9 & 13.7 \\
\hline
\end{tabular}




\section{APPENDIX 8}

APPENDIX 8. Mean values for first and third phalanx measurements of the EBK specimens and comparative material; Equus hemionus, Equus asinus and Equus przewalskii: Dive \&Eisenmann, 1991; Equus hydruntinus (Crimea) and Equus ferus latipes: Kuzmina, 1997; Equus hydruntinus (Lunel-Viel): Bonifay, 1991; Equus ferus gallicus: Eisenmann, online data.

\begin{tabular}{|c|c|c|c|c|c|c|}
\hline Anterior first phalan $x$ & nmax & V7 & V1 & V3 & V4 & V5 \\
\hline EBK small Bb & 1 & 55.1 & 78.8 & 25.6 & 39.8 & 30.1 \\
\hline EBK large $\mathrm{Bb}$ & 1 & 65.7 & 96.1 & 42.7 & 67.0 & 41.5 \\
\hline Equus hemionus & 15 & 48.1 & 76.5 & 24.6 & 41.1 & 30.8 \\
\hline Equus hydruntinus (Crimea) & 69 & - & - & 26.3 & 40.2 & - \\
\hline Equus hydruntinus (Lunel-Viel) & 2 & - & 69.6 & 22.2 & 35.8 & 24.8 \\
\hline Equus asinus & 11 & 46.5 & 72.2 & 23.9 & 38.0 & 28.3 \\
\hline Equus przewalskii & 27 & 51.5 & 78.1 & 32.6 & 49.6 & 33.9 \\
\hline Equus ferus latipes & 95 & - & - & 40.6 & 62.3 & - \\
\hline Equus ferus gallicus & 29 & 58.1 & 85.4 & 37.6 & 57.5 & 38.0 \\
\hline Anterior first phalanx & nmax & V6 & V14 & V10 & V12 & \\
\hline EBK small Bb & 1 & 35.0 & 33.4 & 59.8 & 12.0 & \\
\hline EBK large $\mathrm{Bb}$ & 1 & 55.6 & 50.4 & 70.6 & 15.0 & \\
\hline Equus hemionus & 15 & 36.7 & 35.6 & 58.5 & 10.3 & \\
\hline Equus hydruntinus (Crimea) & 69 & - & 34.3 & - & - & \\
\hline Equus hydruntinus (Lunel-Viel) & 2 & - & 31.9 & - & - & \\
\hline Equus asinus & 11 & 34.5 & 33.6 & 55.2 & 9.9 & \\
\hline Equus przewalskii & 27 & 43.8 & 40.8 & 59.0 & 11.0 & \\
\hline Equus ferus latipes & 95 & - & 50.6 & - & - & \\
\hline Equus ferus gallicus & 29 & 49.4 & 47.0 & 62.2 & 13.1 & \\
\hline Posterior first phalanx & nmax & V7 & V1 & V3 & V4 & V5 \\
\hline EBK small $\mathrm{Bb}$ & 2 & 50.1 & 73.3 & 24.8 & 41.2 & 29.2 \\
\hline Equus hemionus & 15 & 41.8 & 71.2 & 24.3 & 42.4 & 30.9 \\
\hline Equus hydruntinus (Crimea) & 63 & - & - & 24.2 & 39.6 & - \\
\hline Equus hydruntinus (Lunel-Viel) & 7 & - & 63.9 & 21.8 & 37.1 & 24.8 \\
\hline Equus asinus & 10 & 40.8 & 67.5 & 23.2 & 40.0 & 28.4 \\
\hline Posterior first phalanx & nmax & v6 & V14 & V10 & V12 & \\
\hline EBK small Bb & 2 & 32.5 & 30.9 & 55.3 & 12.2 & \\
\hline Equus hemionus & 15 & 35.0 & 33.3 & 52.2 & 12.0 & \\
\hline Equus hydruntinus (Crimea) & 63 & - & 31.8 & - & - & \\
\hline Equus hydruntinus (Lunel-Viel) & 7 & - & 30.8 & - & - & \\
\hline Equus asinus & 10 & 32.9 & 31.2 & 49.9 & 12.0 & \\
\hline Third phalanx & nmax & GB & & & & \\
\hline EBK small $\mathrm{Ba} / \mathrm{Bc}$ & 2 & 56.5 & & & & \\
\hline Equus hemionus & 12 & 54.3 & & & & \\
\hline Equus hydruntinus (Crimea) & 48 & 52.2 & & & & \\
\hline Equus przewalskii & 20 & 70.8 & & & & \\
\hline Equus ferus gallicus & 36 & 80.6 & & & & \\
\hline Equus ferus latipes & 25 & 94.9 & & & & \\
\hline
\end{tabular}




\section{APPENDIX 9}

APPENDIX 9. Scatter plots of measurements on selected dental elements and longbones for the EBK specimens compared with several equid species; $1 . \mathrm{M} 1 / 2 ; 2$. $\mathrm{m} 1 / 2 ; 3$. humerus (breadth of the proximal epiphysis plotted against greatest length); 4. tibia (smallest depth of the diaphysis plotted against greatest length).
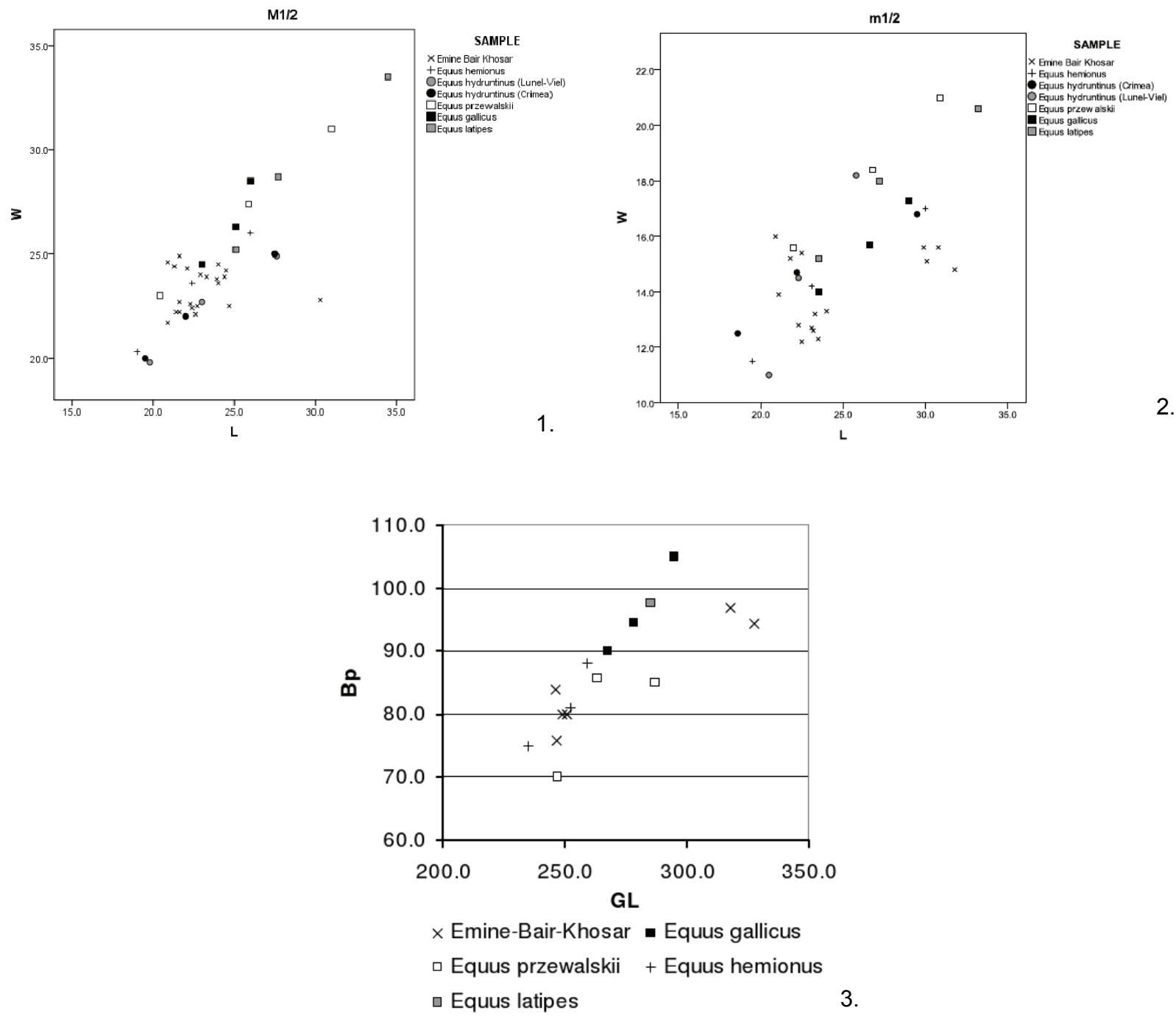